\title{
LA MEJILLA POSTERIOR Perdón y castigo en la literatura comparada
}

\author{
JOAQUín TRUJILLO SILVA* \\ Universidad de Chile
}

\begin{abstract}
RESUMEN: Como introducción a una excursión por varias obras literarias, el ensayo comienza presentando vertientes contrapuestas en las narrativas sobre el castigo: la griega y la hebraica. Muestra la importancia del cristianismo en el concepto de perdón y las nociones generales a él tradicionalmente asociadas, para a continuación detenerse en la idea de perdón: político en una tragedia de Corneille; en una variante spinoziana del perdón teológico con un cuento de Isaac Bashevis Singer; la capacidad de concebirlo en la actividad de la judicatura burguesa en una novela de Kosztolányi; la santidad del perdón en una ópera de Janacek; y finalmente, la imposibilidad de perdonar tomada del análisis del fragmento más representativo de uno de los más famosos poemas de Ajmátova.
\end{abstract}

Palabras clave: perdón, teología, tragedia griega, tragedia francesa, literatura yidish, literatura centroeuropea, poesía rusa.

ABSTRACT: As an introduction to an excursion through several literary materials, this essay begins by presenting opposite strands in the narratives of punishment: the Greek and the Hebrew ones. It shows the importance of Christianism in the concept of forgiveness and the general notions traditionally associated to it, to examine next the idea of forgiveness: political in a Corneille's tragedy; in a spinozian variant of theological forgiveness with an Isaac Bashevis Singer story; the capacity to conceive it in the activity of the bourgeois judicatury in a novel by Kosztolányi; the sanctity of forgiveness on a Janacek opera; and finally, the inability to forgive taken from the analysis of the most representative fragment of one of Ajmátova's most famous poem.

Key words: forgiveness, theology, Greek tragedy, French tragedy, Yidish literature, Central European literature, Russian poetry.

E morto! Orgli perdono

Tosca

\section{INTRODUCCIÓN}

Hay una extensa y fragmentaria narrativa de eventos retributivos en la historia de las formas de conciencia moral. Como en ninguna otra cultura, la griega y la hebraica, desarrollaron las células madres -si se me permite una burda pero efectiva metáfora genetista- para un problema de cuya herencia somos los principales afectados. Por supuesto, ambas genealogías nos conducen hacia eslabones difíciles de rastrear que sin embargo, gracias al estudio del mundo anterior al sincretismo, claramente sabemos distintos el uno del otro. Por una parte, la Grecia arcaica - la de los sucesos transmitidos por la épica homérica y aquellos plasmados en la posterior obra de los tres trágicos- que en gran

\footnotetext{
* Ayudante ad honorem de Historia institucional de Chile, siglos XVI-XVIII y ex ayudante ad honorem de Filosofía Moral.
} 
medida la época clásica "comentó", da cuenta ya de una serie inevitable de actos humanos reñidos con las leyes de los dioses o, en su defecto, las de la rudimentaria polis, actos que en su física y simbólica violencia se van sosteniendo los unos a los otros. Por la otra parte, la historia sagrada de Israel es la de una cadena que ha sabido eludir la avalancha del incontrolable ánimo de revancha mediante el predominio estricto de la ley divina, y, cuando esa sujeción se vio alterada, la condena expresa e hiperconciente de los profetas fiscalizadores; los Jeremías o Nehemías, sin ir más lejos. El predominio de la ley del talión era la renovación permanente de aquella cadena. El cristianismo, un eslabón que quiere interrumpir su cadena misma.

La diversa forma legal en esas culturas así y todo, las aproximaba. "Había en ambas partes - dice Werner Jaeger refiriéndose a la del cristianismo primitivo y a la griega- un intenso deseo de penetración mutua, sin tener en cuenta, por ahora, los reacios a asimilarse que eran estos dos lenguajes, cada uno de los cuales tenía sus diferentes maneras de sentir y de expresarse a sí mismos en forma metafórica" ${ }^{1}$. El pensamiento judío había colaborado antes ya en esta aproximación, que ahora emprendía el cristianismo, mediante Filón de Alejandría, "el prototipo de filósofo judío que ha absorbido toda la tradición griega y hace uso de su rico vocabulario conceptual y de sus medios literarios para probar su punto de vista no a los griegos sino a sus compatriotas judíos" 2 .

Nuestras metáforas acerca del castigo dependen históricamente en gran medida de esta alianza.

Lo que hasta aquí se ha dicho, ilustrémoslo de modo menos opaco. Recordemos, a objeto de repasar el punto griego, la cadena de horrores en el ejemplo tan escalofriante de la familia real micénica. Tántalo mata a su propio hijo Pélope. Los dioses lo vengan, resucitándolo. A continuación, Pélope se casa con la hija de Mírtilo, Hipodamía, y por razones nunca bien claras, mata a su suegro; con lo cual se reactualiza el crimen que contra él cometió Tántalo, su padre. Sin embargo, Mírtilo, antes de morir, maldice a Pélope, maldición que pasa a los hijos de este, Atreo y Tiestes. Y pasa del modo más escalofriante que conocen los mitos griegos. Tiestes y Atreo rivalizan por el trono de Miscenas. Cuando Atreo gana, expulsa a Tiestes y a los hijos de este de la ciudad, pero luego, para vengar el adulterio entre Tiestes y Aérope, su esposa, Atreo invita a volver del exilio a Tiestes acompañado de sus hijos. Los hijos adelantan al padre en el viaje, y cuando Tiestes por fin arriba, su hermano Atreo lo está esperando con un gran banquete de carne exquisitamente asada. Una vez Tiestes ha saciado su hambre, Atreo lo invita a contemplar las cabezas y las manos de los seres que ahora está digiriendo: los propios hijos de Tiestes. Él no quiere defecar la carne de toda su descendencia masculina, pero Atreo ni siquiera le da el beneficio de la muerte a fin de evitar el desecho de una forma peculiar de canibalismo. La cadena de horrores no suele detenerse. En claro contraste, los grandes pecados de los israelitas no traspasan sus culpas más allá de la tercera o cuarta generación. Israel conoce una clausura histórico-familiar de todas las formas de penalidades. Clausura de la cual Dios mismo es garante. La Grecia arcaica ignora los

${ }^{1}$ JaEger, W. Paideia y cristianismo primitivo. Ciudad de México: FCE, 2005, p. 61.

2 Idem., p. 47. 
beneficios de una teogonía racional como la judía, pero no por mucho tiempo. Comprendámoslo continuando el recorrido en el ejemplo de la genealogía real micénica: El famoso hijo de Atreo, Agamenón, a su regreso de una larga participación en le guerra de Troya, será muerto en el baño de su palacio a manos de su propia esposa Clitemnestra -bajo el argumento de que este había sacrificado con anterioridad a la hija común de ellos, Ifigenia- y el amante de esta, Egisto, quien a su vez era hijo de una relación incestuosa entre su padre Tiestes y la hija de este, Pelopia, por lo cual aquel era a la vez primo y sobrino de su víctima. Antes de esto, y tal como los oráculos lo habían predicho, Egisto había asesinado a Atreo, vengando así a sus hermanos-tíos. Pero estos mismos oráculos indican ahora que el asesinato de Agamenón será vengado por el hijo de este y Clitemnestra, Orestes, el cual es salvado de la muerte que su propia madre quiere darle para evitar las profecías, por su hermana Electra. Ella lo envía lejos de la ciudad. Una vez de regreso en Micenas, y ya hecho un hombre, Orestes asistido por Electra da muerte a su madre -quien pide piedad a gritos- y al amante Egisto, vengando así a Agamenón. Esta cadena aún no se detiene. En el instante que Orestes y Electra derraman la sangre materna y la del tío, surgen las bestiales euménides, las furias, en los similares episodios latinos, entidades vengadoras de los crímenes contra los miembros del hogar. Orestes huye durante años de estas presencias, hasta que mediante un juicio en Atenas, Apolo emerge dando protección a Orestes, con lo cual reposa finalmente el torrente del mal micénico.

Hasta aquí he presentado a modo de introducción una apretadísima síntesis de los argumentos de tragedias griegas como La orestíada, trilogía de Esquilo compuesta por Agamenón, Las coéforas y Las euménides; Electra, en las versiones de Sófocles y Eurípides; y de tragedias latinas como Tiestes y Agamenón de Séneca, que aunque muy posteriores a las anteriores siguen en gran medida las ya refinadas concepciones trágicas de la era clásica percicleana.

Veamos un ejemplo para el caso israelita, también al interior de una crónica familiar. José, el hijo penúltimo de Jacob y Raquel, envidiado por sus demás hermanos y medio hermanos a causa de sus sueños premonitorios de superioridad y la predilección paterna de la que goza, es abandonado por ellos al interior de una cisterna seca donde pretenden dejarlo morir. Rubén, uno de los hermanos, persuade a los demás para que lo vendan a una caravana de mercaderes ismaelitas (Génesis 37: 21-27), quienes, a su vez, lo venderán como esclavo, con posterioridad, a Potifar, funcionario egipcio (Génesis 37: 28). La mujer de este último lo acusa de intento de violación. José cae en una especie de prisión (Salmos 105: 17-18). Como José interpreta los sueños, el faraón lo trae a su corte (Génesis 41: 1-36), donde José al ganarse la confianza del faraón, será nombrado segundo gobernante de Egipto. Hasta allí llegarán los hermanos de José para comprar trigo. No lo reconocen; José sí a ellos. En vez de saciarse vengándose, José les perdona, y, es más, su perdón necesariamente se expresa en la ayuda que a ellos les brinda. Definitivamente la historia de José y sus hermanos no se asemeja al relato de la casa micénica en su grado de truculencia. Thomas Mann, ofrece una explicación sugestiva; explicación que está presente también en el paso de los dioses griegos arcaicos a los nuevos, los dioses de la justicia, entre los cuales Apolo destaca. En Las historias de Jaacob, dice: 
Todos sentían como si se les hubieran girado las entrañas y lo de abajo se les hubiera puesto arriba, provocándoles intensas náuseas; y es que en las palabras y la persona del moribundo había algo hondamente sórdido, de una antigüedad horripilante y una santidad anterior a lo santo, algo que yacía debajo de todo el sedimento de la civilización, en las honduras de su alma más evitadas, olvidadas y ajenas al yo, y que la muerte de Yítsjak había hecho emerger en ellos, causándoles la más viva repugnancia: el especto y la sordidez, surgidos de la noche de los tiempos, de la bestia que era Dios, del carnero, Dios-antepasado del clan, del que este descendía y cuya divina sangre ancestral habían derramado y bebido en remotos tiempos obscenos para renovar sus lazos de parentesco tribal con la bestia divina; todo ello antes de que llegara Él, el Dios de la lejanía, Elohim, el Dios de la cumbre lunar, que los había escogido a ellos, que había cortado los lazos que los unían a su naturaleza primitiva, los había esposado mediante el anillo de la circuncisión y había fundado un nuevo inicio divino en el tiempo ${ }^{3}$.

El pensamiento judío, la concepción hebraica del mundo terrenal y extraterrenal realizó un descubrimiento o invención - por ahora, entiéndase como se prefiera- que nuestra época tiende a minusvalorar. Formuló la idea y a veces simple noción de una deidad que por su unidad, su monontología, tendía a reagrupar selectivamente los atributos mutuamente contradictorios del politeísmo - para esta concepción- primitivo, preabrahámico, desde la epistemología de su pueblo. Era un Dios que al desaparecer, al retirarse de la identificación hiperestética (tan egipcia, diría Hegel) de los ídolos con esa divinidad plural; al colocarse más allá del sistema confuso de todas las cosas a partir de las cuales la palabra "Mundo" es hoy predicada a expensas de ese vocablo latino, hizo de sí -o hicieron de él- la invisible objetividad suprema; aquella que al verlo todo, al presenciar todos los objetos físicos e ideales, constituía el único juez de cuya plena justicia, de existir aquel, no podía dudarse. Y sin embargo, el Dios-Juez que también legisla la existencia edénica de la primera pareja, y la castiga al desobedecer, al actuar aquella cual si esa ley no existiera, cual si él no estuviera observando; el Dios que graba la existencia espuria de Caín, una vez este ha matado a Abel, con una señal prohibitiva que impide matarlo, es decir, realizar por una mano no divina la justicia que solo la divinidad se reserva para un tiempo muy posterior; el Dios judío, que sumerge su propia creación bajo el agua y sin embargo de entre toda ella extrae quirúrgicamente aquello que merece y debe salvarse; que, asimismo, en Sodoma sabe de un único "hombre justo", Lot, y lo arranca de la destrucción, simplemente advirtiéndosela; el Dios ejecutor cuyo ángel exterminador se pasea por Egipto cegando la vida de todos sus primogénitos, ese Dios creador (legislador), juez y ejecutor -conforme a nuestras distinciones políticas modernas-, cuya esencia, desde la óptica moral de sus criaturas, es una justicia absoluta, también aparece repleto de las contradicciones fuertemente polémicas de la teogonía griega (aspecto que a ojos de Walt Whitman lo vuelve incomprensible, como al Moisés de Rossini del Mosé in Egitto "Etterno, inmenso e incomprensibili Dio”), y entonces se deja juzgar acaso heréticamente por

\footnotetext{
${ }^{3}$ Mann, Thomas. José y sus hermanos, las historia de Jaacob. Barcelona: Ediciones B, 2000, pp. 206-207.
} 
sus hombres justos, por Job quien sufre una justicia que solo puede concebir injusta. Aquello es lo llamado por Hölderlin Antitheos, es decir: "in Gottes Sinne, wie gegen Gott sich verhält" ${ }^{4}$ (quien "se comporta en el sentido de Dios como si obrara contra Dios"). El Dios-Juez al no impedir la beata acusación de los justos según su ley, reactualiza existencialmente en ellos su calidad teológico-genética de "semejantes" a él, que encontramos en el Génesis. Sin embargo, no eludamos la lectura trágica de esta contrariedad. Hay un problema subyacente a esta calidad antinómica judicial. Un Dios que juzga al hombre justo; el hombre es justo porque "se siente" justo (los dioses hablan a través del corazón, dirá Goethe en su Ifigenia, parafraseando a San Pablo), se concibe a sí mismo actuando conforme a la ley que es, tal como lo es él también, creación de Dios, en tanto Dios no parece dar una pronta respuesta a la acusación, no parece dejarse juzgar por su propia ley, bien porque Dios está siempre más allá de los márgenes de su ley (la estructura legislativa de toda su creación), o bien porque Dios simplemente no existe como entidad distinta de la estructura legislativa de la naturaleza creada. Nótese que la vía para esta última opción pone a la justicia divina por sobre el juez divino, como si el juez ideal y absoluto pudiera equivocarse en la aplicación de la ley que es él mismo, es decir, piensa a Dios como semejante al hombre y no al hombre como semejante a Dios. Ambas relaciones no son lo mismo. Su flujo gramatical es diverso, aunque, concedámoslo, no su significación aritmética. Es bien conocida la obsesión gramático-teológica de las escrituras sagradas hebreas y su aparente indiferencia frente a la helénica proto-metafísica de los significados. La revelación histórica de Dios no se expresa mediante pensamientos, se expresa mediante palabras precisas, lo cual es distinto en el caso del misticismo judío, de los profetas de un mundo interior, psíquico.

Pero volvamos. A esta famosa relación polémica ya enunciada se ha intentado ofrecer una cantidad de respuestas y de contrapreguntas que lamentablemente no conozco ni llegaré a conocer en su totalidad, y aun conociéndolas, no sería este el lugar oportuno para compendiarlas.

La didáctica empleada para la formulación de la problemática antes expuesta, nos permite demarcar una línea relativa a ambos focos, la del juicio mutuo entre Dios, por un lado, y el hombre, por el otro. He aquí entonces nuestra vía de análisis. En esa vía que es un mundo inter regnos, habita una tercera derivada, centro de nuestra atención para los efectos de este ensayo: esa extraña normativa a través de la cual ambos focos se observan mutuamente, juzgándose, y castigándose. El Dios-Juez castiga al hombre en los casos enumerados como en tantos otros; el hombre, en su calidad de crítico -diría Kant-, evalúa la juridicidad de los fallos divinos, y, es más, de la propia ley divina: he aquí el origen del derecho natural en su variante racional e ilustrada (la primordial cuestión kantiana sobre la idoneidad del Juicio), y, con anterioridad a ello, el centro neurálgico de ciertas corrientes teológicas medievales que rechazaron la luminosa procedencia de aquellas escrituras a las cuales los cristianos llaman -acaso nitzscheanamente- Antiguo Testamento. Sin ir más lejos, Kierkegaard está aterrado porque su padre, durante una infancia de hambruna, ha

\footnotetext{
${ }^{4}$ Citado en STEINER, George. Antifonas, la travesia de un mito universal por la historia de occidente. Barcelona: Gedisa,
} 1996, p. 109. 
maldecido al propio Dios 5 . Aquella era la desesperada forma por la que el padre de Kierkegaard quiso darle castigo a una presencia despiadada que no explicaba sus fallos. Kant llega a decir que el sacrificio de Isaac (a su vez brillantemente analizada por Kierkegaard en su Temor y temblor), exigido por Dios al padre de aquel, Abraham, solo puede haber sido solicitado por un demonio ${ }^{6}$. Kant, como sabemos, socorre filosóficamente a Dios reduciéndolo a una incogniscibilidad a partir de la cual solo su forma exterior legal puede ser predicada, ya desde la única y pura perspectiva humana crítica. Así, el Juicio crítico no está dispuesto a reconocer una señal de divinidad en una reclamación carente en lo absoluto de sentido.

Desde aquí podemos entonces avizorar el plano hacia el cual he procurado arrear las consecuencias del problema. A saber, el del castigo con sentido y el del castigo sin sentido.

En los subterráneos murales psiquiátricos de Dostoivesky, que nos son tan conocidos, hallamos casos en estado más o menos puro de castigos con-sentido (factibles de leerse como "consentidos" a Dios por parte del hombre, nótese, obsesión del manoseado "masoquismo" dostoievskiano), castigos que adquieren la nitidez teológica propia de la redención, incomparablemente tratada en Crimen y Castigo como en las novelas de otros rusos del s. XIX cual es el caso de Nikolai Leskov. En las piezas teatrales -diálogos filosóficos escenográficos, habría que decir- de Sartre o Camus tales como Muertos sin sepultura y Los justos, respectivamente $-\mathrm{y}$ solo por nombrar un par-, hallamos magistrales figuraciones del castigo (¿divino?) sin sentido, y de ahí, a propósito de la herencia kantiana, el de la radical imposibilidad ética de Dios, esgrimida por vía de la filosofía existencial francesa.

Ahora bien, al escudriñarse el concepto de castigo sin sentido, y para dicho propósito se recurre a la noción clásica de castigo, aparece la inestabilidad-valiéndonos de la acepción química en su dimensión metafórica para esta expresión- de una tal conjunción. La idea de castigo tiende a caer lejos todavía de los riscos del sin sentido. El castigo puede tener un restringido, mezquino o aparente sentido según la perspectiva crítica acogida, pero difícilmente no tiene ni siquiera un sentido de lógica positivista, que, como se sabe, es el sentido más increíblemente insípido de todos. Hablar, por lo tanto, de un castigo sin-sentido, es solo posible al interior de un campo simbólico donde nada es factible de ser juzgado, y por tanto, la palabra castigo suena a la intromisión de un vocablo recién llegado.

Incluso así, hay un campo crono-lógicamente posterior en donde aun el castigo consentido no tiene sino sentido en el ámbito pantanoso del perdón. Frente a este último, pareciera que el castigo respondería a una reacción inmediatista al daño, a la agresión, todavía demasiado contiguo a la venganza, autotutela de la cual el retribucionismo clásicamente se ha esmerado por apartarse. Ahora bien, ¿cómo habría el castigo de tener sentido en el campo del perdón si supuestamente son campos apartados el uno del otro, cuya definición está conferida por su oposición?

Como se verá, el perdón, y la germinación teológica de ese cataclismo ético en el pensamiento helénico-judío, adquiere recién estabilidad con la incorporación de la historia

\footnotetext{
5 "En 1846 Kierkegaard recordaba: “¡Cuán espantoso es el hecho de que un niño que guardaba ganado en los brezales de Justlandia, sintiéndose adolorido, hambriento y extenuado se pusiera de pie en una colina y maldijera a Dios... y que el hombre fuera incapaz de olvidarlo a los ochenta y dos años". "Citado en STEINER, GEORGE. Idem, p. 79.

${ }^{6}$ KierkegaARD, Sören. Temor y temblor. Buenos Aires: Losada, 1999.
} 
-el discurso profundo acerca del acontecer humano- a una teología que había obtenido su espacio mínimo pero propio en la distancia juiciosa para con el devenir "caído" del Mundo. Aquella teología que trataba a la historia como el ámbito accidentado de una ontología rígida. Detengámonos por un momento en esta relación entre historia y castigo, fundamental al efecto de observar el papel del perdón.

El perdón, que aparece al principio -con la renovación de la ley en Cristo- como una supresión, una aniquilación del castigo, es decir, de la retribución-que asimismo era tenido por supresión de la mera autotutela-, no tendría por qué ser comprendido como una mera donación de nuevo sentido, una relación desprovista de persistente ligadura moral a la manera de una obligación civil o natural en Derecho Civil. Conocemos por el famoso libro de Marcel Mauss Ensayo sobre el don, la estructura de la donación. En aquel contexto, el perdón no es un mero regalo ${ }^{7}$. El perdón es un contrato tácito que se establece entre Dios y el hombre, contrato en el cual este último renuncia a su derecho terrenal a exigir secular castigo para el agresor suyo, y Dios, por su parte, promete premiar aquella extraña forma de renuncia con la salvación de aquel renunciante, en tanto, como DiosJuez - no ya parte en esta relación específica- reordenará el acontecer mediante un juicio postrero, el Juicio Final, donde el gran castigo reaparece suprimiendo para siempre la cadena de la historia nacida del primer pecado y castigo original, la posterior cadena de las agresiones mutuas, y por tanto, tornando inimaginable la necesidad de establecer las relaciones humanas fundada en la amenaza, en la promesa y en la realización del castigo para el caso concreto. Adquiere así nitidez la sentencia de Schiller: "El Juicio Final es la Historia Universal”. En esta manera de presentar el problema, resulta manifiesto que castigo y perdón de ninguna manera corresponden a elementos de una dicotomía. Antes bien, se identificarían cuando se los enfoca desde esta perspectiva estructuralista. Ya, entonces, puede adelantarse la definición de historia sagrada de tal historia. Ello significa que el concepto de historia del que nos hemos valido en este análisis, equivale a un concepto de historia de la humanidad dirigida por la divinidad. Obviamente, en principio, no habría un Juicio Final, un gran castigo, en términos absolutos, de no controlar Dios el libre albedrío final de la humanidad, aunque preserve lo que una óptica ilustrada llamaría el libre albedrío individual.

A partir de este punto, pero con una complejidad de la cual no he dado cuenta, se desarrolló en la Alemania de Hitler un debate iluminador en medio de un tétrico entorno. Karl Barth, el prestigioso teólogo católico contrario al nacionalsocialismo, argumentó contra una tesis teológico-política eminentemente de historia sagrada contemporánea. Ciertos teólogos protestantes filonazis propusieron que Dios intervenía positivamente en la historia política del pueblo alemán. Una idea, cómo se ve, en principio no muy distinta de la propuesta por el obispo de Meaux Jacques Bénigne Bossuet en su Discurso sobre la historia universal, de 1681. Llegaban a esta conclusión impulsados por la fascinación que les provocaba el florecimiento económico y el rudo atletismo cultural que experimentaba Alemania bajo Hitler pese a las singulares condiciones impuestas por el Tratado de Versa-

\footnotetext{
7 LE MAUSS, Marcel. "Ensayo sobre los dones, los intercambios en las sociedades primitivas”, en su Sociología y antropolo-
} gía. Madrid: Tecnos, 1971. 
lles y en el contexto para ellos tan decadentista del ordenamiento constitucional de Weimar. Barth tuvo que argumentar contra esta tesis evitando cualquiera de las variantes a él contemporáneas del aterrador spinozismo. El juicio postrero divino no equivalía, y es más, rechazaba la tesis anteriormente descrita. En su ensayo $A$ través de ese espejo, en enigma, George Steiner explora las consecuencias de dicho planteamiento de Barth ${ }^{8}$. A nosotros nos interesa porque nos presenta una nueva posibilidad crítica: la de la responsabilidad histórica de la divinidad, y de ser ella efectiva, el derecho compensatorio que al hombre concerniría frente a Dios. En dicha posibilidad, Dios aparecería tanto como parte parcialmente comprometida que quedaría inhabilitado como supremo juez. Retorna a nosotros el problema del castigo sin sentido. ¿Qué sentido tendría el veredicto culpable en dicho juicio donde el hombre declara la inhabilidad de un juez que al mismo tiempo legisla? Y, ¿podría allí el perdón renovar su influencia jugando algún papel? En definitiva, ¿podría el hombre perdonar el castigo sin sentido que históricamente la divinidad le inflige?, ¿puede, entonces, el hombre perdonar a su Dios-Juez? Y si lo perdona, ¿no estaría declarando su superioridad moral sobre aquel?, es decir, ¿generando una nueva obligación, y con ello, una resurgente posibilidad de incumplimiento, de daño, y por consiguiente de necesario juicio y entonces, castigo?

Una antropología estructural medianamente avisada, declararía la tautología profunda del itinerario que hasta el final del párrafo anterior hemos trazado. Se trataría otra vez del anteriormente anunciado problema inmanente de la obligación y la deuda por ella generado y aplicado al aparentemente noble asunto de Abraham frente a un único abismo donde se mueven las estrellas, frente a la promesa que le ha hecho Dios; conocido origen de nuestro problema religioso occidental.

¿Y qué hay de quien al confesar persigue ser perdonado? En ese desacreditado procedimiento de higiene espiritual, propio de los católicos, previo a la comunión, se busca una absolución que supone, sin embargo, la superación personal de un pecado que priva a la boca, a la escritura o a los gestos de su función comunicativa: el orgullo. Un pecado que no deja confesar los pecados, y que, por lo tanto, no puede ser confesado sin habérsele, al mismo tiempo, ya superado. En la famosa pieza del nuevo teatro poético inglés ${ }^{9}$, Murder in the cathedral, obra de T. S. Eliot sobre el martirio del arzobispo-canciller de Inglaterra Santo Tomás Beckett, se aparecen, a este personaje, cuatro tentadores. Cada uno le recuerda los aspectos seductores de la vida, aquellos que atan al hombre a ella apartándolo de las muchas veces dolorosas y desagradables santas acciones que incluso pasan por la muerte. Beckett sabe que va a morir si persiste en su debida oposición al Rey Enrique IV. Uno de los tentadores le recuerda las sensualidades de la existencia física, otro, su poderío políticoreligioso, también está el que le propone una alianza con los mezquinos baronets (la SOFOFA del siglo XIII) ${ }^{10}$. Finalmente aparece un tentador imprevisto. Este tentador - "inesperado" dice Eliot- no difiere en ninguna de las profundas convicciones religiosas y ascéticas de Beckett. Esas mismas convicciones que han despedido a los anteriores tenta-

\footnotetext{
8 STEINER, George. "A través de ese espejo, en enigma” en su: Pasión intacta. Madrid: Ediciones Siruela, 1997, p. 442.

${ }^{9}$ Para un estudio breve pero efectivo del mismo Kuna, Franz. El teatro de T. S. Eliot. Ciudad de México: FCE, 1971, pp. 34-61.

${ }_{10}$ ELIOT, T. S. Muerte en la catedral. Madrid: EPESA, 1961.
} 
dores, que se han desecho de ellos. ¿Cómo ellas podrían significar una verdadera tentación? Beckett descubre que la mejor versión de sí mismo es su último tentador, el peor de todos. Es el pecado del orgullo que cree poder comprenderlo todo únicamente desde sí mismo. En tales circunstancias, Dios es para Beckett una mera palabra con la cual él se escuda de los demás, y a partir de la cual se siente autorizado para ejercer sobre ellos un beato dominio espiritual. Porque, para T. S. Eliot, Dios está pidiendo el abandono total, una desnudez expositiva que deje invisible al cuerpo mismo, la confesión absoluta donde el perdón ni siquiera surge de la compensación a la renuncia envuelta en aquella confesión, sino de lo que en teatro se llama deus ex machina, la intervención imprevista, inconceptualizable, a instantes definitivamente absurda, de Dios (típica, sin ir más lejos, de la entrada de Apolo al final de Las euménides de Esquilo). Tan gratuita e inexplicable como la creación del Mundo.

Pero la confesión y el perdón misericordioso de Dios que rehúye el castigo, no fueron exclusividad cristiana. Las Escrituras hebreas están repletas de ejemplos a este respecto. En el Libro de los Números, Moisés impide el castigo de Dios a los israelitas, confesando él mismo la traición de aquellos que pretendían elegir un jefe para volver a Egipto luego de haber sido liberados de la esclavitud, aunque no evita el castigo menor de los cuarenta años (Números, 14-15); asimismo Salomón pide perdón a Dios en la consagración del templo, en el Primer Libro de Reyes (I Reyes, 8:30); Edras reclama el perdón para los judíos expatriados al confesar las culpas de aquellos (Edras: 9:13). Con todo, la ley talmúdica no exigía el perdón en las relaciones privadas.

Ese perdón teologal que libera del castigo, tan querido a Saulo de Tarso, unido al requisito procedimental de la confesión dio lugar a largas polémicas especialmente con ocasión de la reconfiguración del mundo grecolatino inmediatamente posterior al Edicto de Milán (313 D.C.). La tardía persecución a los cristianos renovada por parte del Emperador Decio, había no solo producido muchos mártires; había también llevado a abjurar - “apostatar” es el término específico- a muchos otros cristianos. El apelativos de Lapsi (del singular latino lapsus: caído) mediante el cual se hacía referencia al grupo indeseable de dichos apóstatas, no fue tan solo una acusación recurrente al interior de la Iglesia, dio origen al interior también de esta a un debate del cual participó, según la leyenda, hasta el mismísimo Emperador Constantino. Basándose principalmente en párrafos de los libros de Josué e Isaías (Josué 24: 19-20 e Isaías 2: 6-9) o aquel donde el apóstol Pedro compara a quienes vuelven a su vida pecadora, con una cerda que luego de bañada se hunde en el lodo (2 Pedro, 2: 22) entre otros, el Obispo Accesio insistía en que la Iglesia no podía perdonar a aquel grupo. Tan solo Dios en la muerte de cada uno de ellos. La confesión, como refundación de la historia moral de cada miembro de la comunidad religiosa, no podía ser administrada por el sacerdote. Se cuenta que durante el concilio reunido al efecto, Constantino intervino diciendo: "Accesio, pon una escalera y sube solo al Cielo". Estas palabras que, telescópico, el Emperador podría haber dedicado al Wittgenstein del Tractatus (de seguro, este último se interpuso en el trayecto de esta metáfora para explicitar la pedante conciencia de su encumbramiento lógico-filosófico), registran la relación contradictoria no indisoluble entre orgullo y confesión, y, entonces, entre orgullo y perdón. Pero nuestra referencia a Wittgenstein no es antojadiza. "Una confesión debe ser parte de 
la nueva vida"11, dice. Este aforismo incluido en la selección de observaciones que armaran Georg Henrik von Wright y Heikki Nyman, tiene la fuerza de una objeción propia de Epícteto. Una singular nota del 18 de julio de 1916, adelanta la anterior elucubración epicteteana de 1931: "Para la vida en el presente no hay muerte./ La muerte es una parte de la vida" 12 . La confesión es ya parte de la nueva vida, una vez esta ha hecho su aparición sensible. ¿Cómo, entonces, la antigua vida podrá realmente revelarse (y rebelarse contra sí misma) sin la asistencia de ese don que es la vida nueva, la vita nuova de la cual había hablado amorosa y teologalmente Dante según su teoría de la expresión del agente? Al parecer, Wittgenstein nos está sugiriendo que el tránsito entre la antigua vida pecadora y la nueva, en el cristianismo, está mediado por un giro trágico. No es la sola voluntad del hombre la que allí ha operado; son las fuerzas de los dioses otra vez. Pero ha sido necesario indagar en la gramática de este aforismo para descubrirlo. Habría que reconsiderar aquí, una de las lecciones del curso dado por Heidegger sobre La fenomenología del espiritu de Hegel en el semestre del invierno de 1930-1931 en la Universidad de Friburgo. "El saber absoluto -dice, pedagógicamente, Heidegger- debe ser otro al inicio de la experiencia que la conciencia hace consigo, experiencia que, más aún, no es otra que el movimiento, la historia donde acontece el llegar-a-sí-mismo en el devenir-se-otro" ${ }^{13}$. La explicación que Heidegger hace de Hegel considera a la transformación de la conciencia una condición de ser conciencia. Nos interesa que no se pasa de un campo a otro por simple obra del moviendo, sino del segundo campo. Cuando nuestros pies se elevan, es porque una montaña se ha elevado bajo nosotros.

La novedad, el secreto de confesión, vino a excluir a la comunidad cristiana del espectáculo del perdón. Bogomilos, albigenses, cátaros, valdenses, y otras sectas cristianas y pseudocristianas tardomedievales - reivincadas por Simone Weil ${ }^{14}$ e investigadas en el siglo XX por el siniestro Otto Rahm ${ }^{15}$ - acusaron la supuesta hipocresía de este perdón secreto, y para evitarlo, incorporaron a sus sobrios rituales un sistema de confesiones públicas al modo de la tendencia general en la iglesia primitiva. La tan abierta exposición de los malos actos, en un contexto extremadamente puritano, por parte de los grupos franceses redundaría en una extraña sanidad en la convivencia pacífica de estos en el Mediodía, y en el aprovechamiento publicitario de Simón de Montfort o el abad cisterciense Arnarld Amalrich, los líderes de la tristemente célebre cruzada al interior de Europa contra aquellos grupos predicada por el papa Inocencio III -según el dialogante Daniel Rops, "el Papa más brillante de la Edad Media"16_ mediante la cual finalmente se los aniquiló casi por completo. Como se ve, una confesión total dio lugar a un total castigo. No se confesaban al oído de un cura.

El punto no es anecdótico. La dimensión política del perdón está, según Hannah Arendt, en el centro del mensaje de Jesús de Nazaret:

\footnotetext{
11 Wittgenstein, L.. Observaciones. Ciudad de México: Siglo veintiuno editores, 1981, p. 42.

12 Wittgenstein, L.. Diario filosófico (1914-1916). Planeta-De Agostini, 1986, p. 129.

${ }^{13}$ Heidegger, Martin. La fenomenología del espiritu de Hegel. Madrid: Alianza Editorial, 1992.

${ }^{14}$ STEIner, George. “Santa Simone: Simone Weil” en su Pasión intacta. Madrid: Ediciones Siruela, 1997, pp. $183-196$.

15 Markale, Jean. El enigma de los cátaros, la masacre de Montségur, Buenos Aires: El Ateneo, 2008.

${ }^{16}$ Rops, Daniel. La iglesia de la catedral y la cruzada. Barcelona: Luis de Caralt, 1956, p. 507.
} 
En nuestro contexto es decisivo el hecho de que Jesús mantenga en contra de los "escribas y los fariseos" no ser cierto que solo Dios tiene el poder de perdonar, y que este poder no deriva de Dios - como si Dios, no los hombres, perdonara mediante el intercambio de los seres humanos-, sino que, por el contrario, lo han de poner los hombres en su recíproca relación para que Dios les perdone también ${ }^{17}$.

Pero hay, siguiendo con Arendt, un fundamento lógico para esta dimensión del perdón: "(...) nadie puede personarse ni sentirse ligado por una promesa únicamente hecha ante sí mismo; el perdón y la promesa realizados en soledad o aislamiento carecen de realidad y no tienen otro significado que el de un papel desempeñado ante el yo de uno mismo"18, en la consideración de Arendt según la cual perdón y promesas en tanto facultades "las dos van juntas, (...) una de ellas, el perdonar, sirve para deshacer los actos del pasado (...); y la otra, al obligar mediante promesas, sirve para en el océano de inseguridad, que es el futuro por definición, islas de seguridad sin las que ni siquiera la continuidad, menos aún la duración de cualquier clase, sería posible en las relaciones entre los hombres" ${ }^{19}$.

En Fantine, el Obispo Myriel, retrato de aquella antigua nobleza parlamentaria del Mediodía, aniquilada por la Revolución Francesa, especie de perfecto cátaro pero católico, se ha erigido en la representación óptima del prelado cristiano aristocrático enemigo de los ricos - una clase a la cual él ya no pertenece ni lo quiere- y defensor a ultranza de los miserables. Este prelado que ha sido modelo para tantas reformulaciones de la espiritualidad católica francesa, está detrás del eminente cura de Torcy, en Diario de un cura rural, quizás, junto a Bajo el sol de Satán, la novela más impresionante de Georges Bernanos.

Contra la inspirada meditación acerca del verdugo de Joseph de Maistre, recogida en Las veladas de San Petersburgo, y a favor del enfoque de Cesare Beccaria, Hugo anota la siguiente reflexión sobre la supuestamente neutral maquinaria del castigo:

El cadalso es una visión. No es un tablado, no es una máquina, no es un mecanismo inerte hecho de madera, de hierro y de cuerdas. Parece una especie de ser que tiene no sabemos qué sombría iniciativa. Se diría que esa estructura ve, que esa máquina oye, que ese mecanismo comprende, que ese hierro, esa madera y esas cuerdas tienen voluntad. En el horrible ensueño en aquella esa visión sume al alma, el cadalso aparece terrible y como si tuviese conciencia de lo que hace. El cadalso es el cómplice del verdugo; devora, come carne, bebe sangre. El cadalso es una especie de monstruo fabricado por el juez y el carpintero; un espectro que parece vivir una especie de vida espantosa hecha con todas las muertes que ha dado ${ }^{20}$.

El sacerdote había asistido a un saltimbanqui condenado a muerte. Las reflexiones de Hugo a propósito de aquella supuesta neutralidad moral, irán más allá y nos dan espacio a desdibujar la noción del Dios-Juez a la que hemos puesto una atención desmedi-

\footnotetext{
17 ARENDT, Hannah. La condición humana. Barcelona: Paidós, 1993, p. 259

18 Idem.

${ }^{19}$ Ibid., pp. 256-257.

${ }^{20}$ Hugo, Victor. Los Miserables. Buenos Aires: Longseller, 2006, p. 32.
} 
da. El pudor francés de Hugo no le permitiría haber aceptado como reflexión enteramente propia, esta anotación bossuetiana -digámoslo así- que él atribuye a su amada creación, el piadoso obispo de Digne, Monseñor Charles-François-Bienvenu Myriel:

¡Oh, Tú! ¿quién eres?

El Eclesiastés te llama Todopoderoso; los macabeos te llaman Creador; la epístola a los Efesios te llama Libertad; Baruch te llama Inmensidad; los Salmos te llaman Sabiduría y Verdad; Juan te llama Luz; los Reyes te nombran Señor; el Éxodo te llama Providencia; el Levítico, Santidad; Edras, Justicia; la Creación te llama Dios; el hombre te llama Padre; pero Salomón te llama Misericordia, y este es el más bello de todos los nombres ${ }^{21}$.

"Misericordia es el más bello de tus nombres". El Obispo Myriel salvará a Jean Valjean, el protagonista de Los miserables, oyendo una confesión enteramente silenciosa. Perdonando sin necesitar de arrepentimiento efectista, el obispo dirá a los policías que los candelabros que Valjean le había hurtado, eran un regalo para aquel.

Ahora bien, escapemos a este enfoque excesivamente teológico. En La condición humana-siempre la de Hannah Arendt-, y específicamente en el apartado 33 "Irreversibilidad y poder del perdón", en ese magistral capítulo arriba ya citado que es "Acción", hallamos una kantiana y a su vez escolástica -si se me permite esta antojadiza figura de dicción- teoría acerca de la relación entre las facultades del perdón y la promesa correspondientes a la "condición humana de la pluralidad" 22 . Arendt presenta la triada de vértices incompatibles: perdón - castigo - venganza; la cual presenta a la "venganza" como el origen de la cadena griega a la cual nos hemos referido, mientras que el "castigo" y el "perdón" serían, en definitiva, ambos formas "que intentan finalizar algo que sin interferencia proseguiría inacabablemente" 23 . Lo aquí muy interesante $-y$ lo específico del perdón, y ahora además, en contraste con la venganza- es que:

[E]l acto de perdonar no puede predecirse; es la única reacción que actúa de manera inesperada y retiene así, aunque sea una reacción, algo del carácter original de la acción. Dicho con otras palabras, perdonar es la única reacción que no re-actúa, simplemente, sino que actúa de nuevo y de forma inesperada, no condicionada por el acto que la provocó y por lo tanto libre de sus consecuencias, lo mismo quien perdona que aquel que es perdonado. La libertad contenida en la doctrina de Jesús sobre el perdón es liberarse de la venganza, que incluye tanto al agente como al paciente en el inexorable automatismo del proceso de la acción, que por sí misma nunca necesita finalizar ${ }^{24}$.

Lo inesperado del perdón no puede convivir con la cadena de las reacciones morales sino como un nuevo origen, un origen, que a diferencia del castigo, no se realiza en tanto

${ }^{21}$ Ibid., p. 35.

22 ARENDT, Hannah, op. cit. (n. 17), p. 257.

23 Ibid., p. 260.

${ }^{24}$ Idem. 
punto aparte. Así el perdón rompe con aquella inevitabilidad trágica más propia de los griegos que de los romanos. El único movimiento que inevitablemente lo provoca, es el mal, porque el perdón no actúa ex nihilo, actúa sobre una falta provista de cierta especificidad. El castigo contrarresta, según la clásica teoría retribucionista, aplicando diversos grados de mal sobre un mal menos institucional; en el perdón, en tanto, quien perdona se traga la reacción natural que es la venganza, y prescinde de activar la reacción institucional -religiosa, jurídica o política- que es el castigo, cuyo sentido, ya descrito, descansa precisamente en aquel revestimiento institucional.

Habida cuenta del entramado de conceptos presentados y como no es mi propósito ni me hallo capaz tampoco de teorizar sobre un asunto tan escurridizo como el perdón a raíz del castigo, me concentraré en una casuística de ciertas obras europeas donde el tratamiento de este asunto es de lo más interesante e iluminador y acaso podrían llegar a presentarse a modo de ejemplos paradigmáticos. Una pieza trágica de Corneille; una novela de Kosztolányi; un cuento de Isaac Bashevis Singer y una ópera de Janácek. Solo para ello me hallo aquí intelectualmente competente.

¿Por qué no referirse al castigo y al perdón en la segunda parte del Fausto de Goethe o a la penitencia y la confesión de Dante en el trigésimo primer canto del Purgatorio, cántica intermedia de ese enorme cuadro poético teológico que es La Divina Comedia? Me parece que acerca de este tema, en estos fragmentos maravillosos específicos, existe una inmensa literatura especializada. Será entonces más interesante para mí y menos perjudicial para los lectores, ilustrarlo en obras que han gozado de menos difusión en habla castellana.

Con parcere subiectis los romanos se referían al indulto que se debe al vencido ${ }^{25}$. El célebre episodio romano del extraño perdón que el Emperador Octavio Augusto dio a los miembros de una conspiración contra él urdida, al interior de la cual se encontraban hombres y mujeres muy cercanos, magistralmente comentado por Séneca en el capítulo IX del primer libro de su tratado De Clementia ${ }^{26}$, y desarrollado en el libro LIV de la Historia de Roma $^{27}$ de Dión Casio, dio a Corneille un gran tema para en 1640 hacer representar Cinna o La Clémence d'Auguste, impresionante tragedia política y amorosa, que a su vez dio asunto al libreto de Pietro Metastasio para la adaptación realizada por Caterino Mazzola de la cual W. A. Mozart se sirvió para su famosísima ópera La clemenza di Tito de 1791, que los chilenos hemos tenido ocasión de ver representada.

Presente en el estreno en Praga de la versión de Mozart, se cuenta que la Emperatriz María Luisa no la perdonó, refiriéndose a ella como a "una porcheria tedesca"28 ("Una porquería alemana”). En el ambiente cosmopolita y europeizante de la Casa de Habsburgo,

\footnotetext{
25 ARENDT, Hannah, op. cit. (n. 17), p. 259.

26 SÉnECA, Lucio Anneo. "De la clemencia" en su Tratados morales. Ciudad de México: Universidad Autónoma de México, 1944.

27 DiOn CASIO. Historia de Roma. Madrid: Gredos, 2004.

28 JACOBS, René. "Sept idées fixes (et fausses) su La Clemence de Titus" en su: La clemenza di Tito. Italia: Harmonia Mundi, 2006, p. 20.
} 
por mucho que la ópera recogiera un tema que celebraba la altura moral imperial, pesaba más el carácter enfadado de ópera seria, un carácter del cual la tan sobria y entonces criticada renovación de Glück -alemán querido en París- era responsable por filiación aunque indirecta. La distinta suerte de una también prejuiciosa percepción pero en su cara positiva, recibió la original tragedia de Corneille. A la nobleza de tiempos del Cardenal Mazzarino fascinó la compleja conspiración en la cual veían escrupulosa y anacrónicamente proyectada la época de La Fronde de la que ella se sentía tan frívolamente autora. Mas, como veremos, la nobleza francesa en realidad se fascinaba con la deformidad de su propia lente. El cosmos del que hablaba la tragedia de Corneille se movía en una dirección ni siquiera opuesta.

En resumidas cuentas, el argumento es el siguiente.

Octavio Augusto se ha hecho con el poder total del Imperio Romano. En su casa ha adoptado como hija suya a una de las hijas de sus vencidos enemigos políticos, Emilia. Ella empuja a su enamorado Cinna a comandar junto al amigo de este, Máximo, un grupo de conspiradores cuya finalidad pasa por la muerte de Octavio Augusto. Octavio manda llamar a los amigos. Emilia cree que la conspiración ha sido descubierta, sin embargo, Octavio Augusto les hace partícipes de su deseo de abandonar el poder de Roma ya harto de la odiosidad que su figura concita. Contra lo previsto, Cinna y Máximo exponen al emperador sus convicciones políticas: lo instan a continuar ejerciendo la autoridad imperial. Una vez solos, Cinna confiesa a Máximo que, en realidad, su participación en la conjura contra Octavio se debe a su amor por Emilia. Celoso, Máximo, quien secretamente desea a la enamorada de su amigo, decide delatar a Cinna frente a Octavio, quien tiene en ambos a sus preferidos. Mientras tanto, Cinna se muestra dudoso de proseguir en la conspiración ante Emilia, quien lo amenaza: Luego, Máximo, creyendo que Cinna morirá, declara su amor a Emilia y su intención de desistir del asesinato de Octavio. "¿Te atreves a amarme y no te atreves a morir?"29, le pregunta ella, desdeñosa. Otavio Augusto es convencido por su mujer Fulvia de perdonar a Cinna. Octavio manda a llamar a Cinna. Le hace saber que él está al tanto de todo. Aparece Emilia y se declara la secreta cabeza del movimiento. “'También tú, hija mía!”30, exclama Octavio Augusto a imitación de Julio César ante Bruto cuando este lo mataba. "Sí -responde Emilia, en defensa de Cinna-. Todo lo que él ha hecho ha sido por complacerme. Yo era la causa y la recompensa"31.

Emilia, una Electra ya no hogareña sino de connotaciones políticas -Augusto había matado al padre de Emilia, y adoptado a esta- presentes desde el Renacimiento, posee pareja erótica pero sin contacto sexual desde hace cuatro años, cual la Electra desposada pero virgen de Eurípides, la Emilia de Corneille está centrada en la aniquilación del tirano aunque ello pase por la de su amor Cinna. El discurso de Emilia al respecto, donde planifica el atentado contra Augusto, podría pertenecer a Los justos de Camus:

Aunque Augusto esté defendido por muchas legiones, por muchas precauciones que tenga y por mucho orden que siga, quien desprecie su propia vida, es dueño de la suya. Cuando mayor es el peligro, más dulce es el fruto. La virtud nos lanza y la

\footnotetext{
${ }^{29}$ Corneille, Pierre. “Cinna” en su Teatro trágico, Madrid: Emecé, 1968, p. 198.

${ }^{30}$ Idem, p. 204.

${ }^{31}$ Idem.
} 
gloria nos sigue. Sea lo que sea, perezca Cinna o Augusto, debo a los manes paternos este sacrificio ${ }^{32}$.

Hannah Arendt ha sostenido que el amor sea "quizás la más fuerte de todas las fuerzas antipolíticas humanas" 33 . Pero George Steiner ve en Cinna la tragedia del amor subyugado por la política ${ }^{34}$. Seguramente la -pese a todo- apasiona Arendt ve en el amor todo aquello que el descreído Steiner no ve -pese a sus últimas paráfrasis sexuales- en su miopía sentimental. Empero, y como veremos, Corneille conseguirá desarmar el aparentemente trágico enfrentamiento entre amor/política con un enfrentamiento menos concreto, más abstracto y maligno: el de política contra política.

Descubierta por Augusto, ella expone sus razones cuando aquel le reprocha a ella los cuidados que le brindó tal -responde Emilia- los que su padre verdadero brindó a Augusto:

Con la misma abnegada ternura elevó él la vuestra, que "él fue vuestro tutor y vos su asesino. Vos me habéis enseñado el camino del crimen. Él mío solo es diferente del vuestro en un punto: que vuestra ambición inmoló a mi padre y que mi justa cólera, que me abrasa entera, quería inmolar a su sangre inocente la vuestra culpable ${ }^{35}$.

La estructura de la descontrolada justicia griega aparece nuevamente. Emilia quiere implantarle la moderación de una intención moral: la de ella es la cólera, la de Augusto, en tanto, fue la ambición. Más tarde, Emilia reconocerá que el perdón de Augusto borra las aristas mutuamente irreconciliables del castigo:

Cinna es la tragedia de la política moderna, aquella forma de entender la política liberada a todas sus posibilidades causales, al laberinto infinito de los cálculos donde el amor sí aparece como una virtud, pero una virtud devaluada frente a la urgencia del enfrentamiento polémico. Corneille como autor político ha servido de pretexto a políticos y filósofos franceses. En La muerte de la tragedia, George Steiner señala que el General De Gaulle incorporaba en sus discursos intertextos extraídos del Horace de Corneille con la mayor naturalidad y ausencia de efectismo ${ }^{36}$; asimismo, durante las tertulias en casa de sus benefactores, los Duplay, el inclemente Robespierre leía fragmentos "de Voltaire, Rousseau y Corneille" 37 ; desde Gabriel Marcel, en el drama Roma ya no está en Roma, a L'Éscriture et la différence de Jacques Derrida, la filosofía francesa ha hecho exégesis de Le Cyr.

La dramaturgia de Corneille conoce una forma demasiado prístina de psicoanálisis. El discurso privado que Octavio da a Cinna en la escena I del acto V significa toda una sesión de provocativa terapia:

Aprende a conocerte, penetra en ti mismo. Se te honra en toda Roma, se te corteja, se te aprecia; todos tiemblan ante ti, todos te ofrecen sus mejores votos; grande es tu

\footnotetext{
32 Ibid., p. 168.

33 ARENDT, Hannah, op. cit. (n. 17), p. 261.

${ }^{34}$ STEINER, George. La muerte de la tragedia. Caracas: Monte Ávila, 1970.

35 Corneille, Pierre, op. cit. (n. 31), p. 205.

36 Idem.

37 JORDAN, David P. Robespierre, el primer revolucionario. Barcelona: Vergara, 2004, p. 79.
} 
fortuna, consigues todo lo que pretendes; pero darías lástima a los mismos que ahora te envidian si yo te abandonase a tu escaso mérito. Atrévete a desmentirme, dime cuáles son tus talentos; háblame de tus virtudes, de tus gloriosos trabajos, de las raras cualidades por las que has conseguido mi aprecio, de todo lo que te eleva por encima de lo vulgar ${ }^{38}$.

Los personajes de Corneille realizan razonamientos lógicamente intachables. Sin embargo, el autor no por ello parecerá preferir al mentiroso coherente sobre el veraz contradictorio. No sería tan intelectualmente mezquino como para ofrecernos tal dicotomía. Con la mayor soltura aristocrática, estos personajes exploran su inconsciente y el de los demás, exponiéndolo con un dominio consciente que el teatro alemán desde George Büchner declarará insoportable. En su maquiavelismo transparentado, no pecan de ingenuidad política. Esta fácil neuroplasticidad de la psiquis teatral corneilleana siempre abarcadora de todo cuando espacio sea contemplado, pone a los elementos del conflicto aristotélico -al que en Cinna Corneille quiso estrictamente ceñirse- en una común línea de flotación que niega las particularidades relativas a aquellos también particulares elementos. En los personajes de Jean Racine -en cambio- conoceremos el lenguaje supuesto de una introversión, de una contención del habla desesperada que en Fédre alcanzó un punto al cual el teatro francés no pudo regresar ni siquiera con Ionesco o en El emisario de Marcel.

La magnanimidad del perdón, una virtud política solo posible de desarrollarse, según Corneille, en el supercontexto de un poder estatal que en tanto tal ha doblegado al poder privado común a las familias patricias. Desde ya pueden oírse de fondo las voces protoabsolutistas de un Bossuet o un Jean Bodin, no obstante, apuntar la reflexión corneilleana más allá de otra justificación más de la monarquía católica francesa contra el pseudoanarquismo refinado y belicoso de las grandes familias de Francia.

Así, el atentado contra Augusto no aparece cual un delito tipificado, pero sí cual un atentado contra la orgánica fundamental del Estado que Augusto encarna en su calidad de vencedor absoluto. Lo dice Corneille mediante Livia:

Todos los crímenes de estado que se cometen para alcanzar la corona, el cielo nos los perdona en el momento que nos la entrega y, una vez en la categoría que su gracia les ha dispensado, lo pasado se hace justo y le está permitido contar con el futuro. Quien puede alcanzar el cetro no es culpable; hiciera lo que fuese, haga lo que sea, es inviolable, le debemos nuestros bienes, nuestras vidas están en sus manos, y jamás se tienen derechos sobre los de los reyes ${ }^{39}$.

En efecto, Corneille está presentando una teoría acerca de la relación entre el Estado, Dios, y el tiempo. Un estado funciona porque actúa conforme a la naturaleza de su poder; ese poder no es mera fuerza, sino poder en su sentido menos violento, más legítimo, porque su estabilidad demuestra conformidad con las leyes del cielo, la legislación divina. En tales circunstancias, la legitimidad de su estabilidad duradera acaba por silen-

38 Corneille, Pierre. "Cinna" en su Teatro trágico. Madrid: Emecé, 1968, p. 203.

39 Idem, p. 205. 
ciar los actos de barbarie (que le son reprochados) a partir de los cuales ha sido fundado su valor específico de antibarbarie. De tal manera, la presencia del pasado violento minimizada significa el predominio existencial del futuro, de la esperanza. Porque el Estado nos ha permitido gozar de la esperanza del futuro es que toda nuestra estabilidad (nuestra vida, nuestros bienes), en última instancia se los debemos. Cómo se ve, esta es una de las lecturas de Robespierre, un profundo moralista que creía que la funcionalidad futura de su política, disculparía la violencia entonces ya pasada de esa política.

En su calidad de admirador y defensor de los actores, tribuno de la plebe en la Asamblea Constituyente, y lector incansable de Corneille, Robespierre consideraba que el teatro era la escuela moral de los ciudadanos, tenía del fenómeno teatral una idea no puramente estética, sino antes bien, ética. Para él la refundación política de Francia, la Revolución, comenzaba por una moralidad sumamente estricta que residía en el alma. Como estudioso de la retórica latina, sabía que según Cicerón, la oratoria era una actividad del alma en relación con las almas de los otros. La generación de esta comunión sanamente retórica Robespierre la veía en la nitidez expresiva de los personajes de Corneille, y en su propia labor de orador, de abogado movido por los principios de su profesión y no por los tecnicismos de la disciplina -en suma, de abogado no de parte, sino de la totalidad ya formulada por Rousseau-, de expresión ilustrada y clásica del retóricamente inexpresivo clamor popular. Como moralista revolucionario es importante atender a la cultura teatral neoclásica francesa de Robespierre, a su noción de reconfiguración moral y teatral de su época; moral en los principios y teatral en la expresión de los mismos ${ }^{40}$. ¿Por qué sacar a colación esta relación a propósito de este análisis? Porque la idea de dictadura para el monarca Augusto de Corneille como para el demócrata Robespierre de Maximiliano Robespierre, el abogado de Arres, no se clausura negativamente. Para ambos personajes, la dictadura no es una tiranía irredimible. Revestida de virtud cívica, la dictadura del pueblo está en armonía con la dirección anímica de la inteligencia de cuya encarnación Robespierre o Augusto son ejemplos, quienes obran desinteresadamente en pos de los intereses comunes a todos, la totalidad roussoniana. No son dictadores que se llenan los bolsillos. La aristocracia no sabría practicar esta virtud sin atentar contra sí misma. De ahí su tendencia inmodificable a devenir en oligarquía. Pero estas ideas también sirven al contrario, a la contrarrevolución. Uno de los precursores de la unificación alemana, participante del Congreso de Viena, y asesor político brillante en Prusia como en San Petersburgo, el barón Karl von Stein, detectará la importancia de robustecer la alianza entre el pueblo y el monarca en atención a debilitar la aristocracia, que él mismo intentó mediante un proyecto de abolición de la servidumbre en Prusia bajo Federico Guillermo III. Lo que separa, sin embardo, al Octavio Augusto de Corneille y al Robespierre que él hizo de sí, lo que los hace irreconciliables es precisamente la capacidad psicológica o política -no lo sépara ponerse por sobre los acontecimientos. Octavio Augusto ha recogido su poder en este mundo, pero siente transcenderlo. Sus enemigos son para él, enemigos de una imagen equivocada. Una vez sus enemigos llegan realmente a conocerlo -él los perdona- se realiza la reconciliación esperada. Robespierre, en tanto, es un mesías que no está por sobre el

\footnotetext{
${ }^{40}$ A este respecto, véase los sugerentes argumentos en JORDAN, David P, op. cit. (n. 37), p. 100 y siguientes.
} 
pueblo cuya opinión virtuosamente guía. Los enemigos suyos, son enemigos de la revolución, son contrarios perfectos, aunque moralmente equivocados. Perdonarlos sería la ruina de un mundo en construcción donde pueda perdonarse virtuosa y no cobardemente. Charlotte Robespierre, su hermana, contaba que antes de ir a París como delegado a la Asamblea Constituyente, en Arres, Robespierre no quería, en su calidad de juez de provincia, firmar la condena a muerte de un criminal $^{41}$. ¿Por qué entonces no perdonó a sus enemigos? Porque no eran sus enemigos, eran los enemigos de la mayoría, de la cual él era, paradójicamente, vocero y el guía más intelectualmente adecuado.

Friedrich von Schiller -admirador de Corneille y Racine- reconoció en su tragedia Marie Stuard, la intrínseca ausencia de vocación compasiva en la política moderna. En esta muy propia versión de los últimos días de María Stuardo, una exquisita intriga político religiosa, plagada de arrojadas conspiraciones "de papistas desaforados" y de las reacciones de los partidarios isabelinos, la Reina Isabel I se da a un egotista cálculo a fin de conservar para sí el inestable poder del cual dispone. Se percata de que para conservarlo y acrecentarlo necesita decidirse a ser la cabeza de la Iglesia de Inglaterra, única manera de poner fuera de juego a su rival, la María Stuardo católica romana. Necesita Isabel desconocer al papado para no ser la "bastarda" - como la llama María-. Muy enterada de los debates acerca de su legitimidad para ocupar el trono, debe eliminar a María, posible competencia, pero también no puede mostrarse accesible a las presiones del pueblo que quiere ver a María ejecutada. María invoca el derecho de gentes por el cual en su carácter de reina de Escocia, no podía ser juzgada por un tribunal inglés. Pero Isabel necesita afirmar su autoridad política mediante el desconocimiento de la tradición católica europea. Deja pasar una semana y no accede a formar el indulto de María ${ }^{42}$, luego accede a las presiones del pópulo, pero siempre retrocediendo: "El pueblo amotinado instaba a que firmase, y siendo obedecerle, firmé, pero cediendo a la coacción..., os entregué la sentencia para ganar tiempo... Ahora, dádmela otra vez..." 43 .

En la Isabel de Inglaterra, de Ferdinand Bruckner, hay carencia de piedad, la tendencia a hacer del castigo su política, dice relación con una anomalía psicológica. Isabel es una mujer insegura, agobiada por falsos pretendientes a quienes se agobia por desenmascarar ${ }^{44}$.

Basada en la heteroisabelina pieza The beggar's opera de John Gay, la célebre Die Dreigroschenoper de Bertolt Brecht, impuso una ultrairónica concepción del indulto monárquico. El maleante Mackie Messer, en el tercer final de la obra, es rescatado de la horca a último momento por un emisario de la reina, quien anuncia que el malhechor ha sido perdonado, se le dará una renta anual y un título nobiliario. Los mendigos celebran el triunfo aspiracional de un, como ellos, antisocial. Brecht presenta el indulto a los supuestamente desfavorecidos en la sociedad burguesa como una manipulación que esa sociedad hace de sí misma para regenerar las estructuras de dominación, según el estudio que Brecht hizo de las tesis de Marx a través de Karl Krosch ${ }^{45}$.

\footnotetext{
${ }^{41}$ JORDAN, David P, op. cit. (n. 37) p. 42.

42 SCHILler, Johann Friedrich. María Estuardo. Madrid: Club internacional del libro, 1998.

43 Idem, p. 110.

${ }^{44}$ BRUCKNER, Ferdinand. Isabel de Inglaterra. Buenos Aires: Nueva Visión, 1961.

45 ChIARINI, Paolo. Bertolt Brecht. Barcelona: Nexos, 1994.
} 
Sin embargo, ¿Corneille se refiere a un desinteresado armisticio? Ese armisticio que frecuentemente busca una interesada reconciliación. El de Octavio no es la amnistía que siguió a la sublevación de los comuneros españoles al llevarse a cabo la elevación de Carlos I de España y V de Alemania, y que el emperador finalmente perdonó en pos de empresas europeas que lo obsesionaban tales como la recuperación de su "ancien herencia paterne" 46 ("antigua herencia paterna"). No es tampoco un pacto de no agresión civil, de reconciliación armada, cuando la proporcionalidades congruentes de las fuerzas en combate hacen inviable la supremacía de alguna de ellas al objeto del retorno a la calma, cual fue el caso en Francia al la Reina Catalina di Medicis casar a su hija Margot con Enrique de Navarra - protestante- a fin de sosegar el ánimo a sus súbditos hugonotes que comandados por Coligny escindían el reino. Esas fuerzas de grados similares solo pueden destruir todo a su alrededor antes de por fin aniquilarse mutuamente. Pero Octavio Augusto es una fuerza tan superior que no entra en negociaciones de paz, no cede, pero sí perdona a los ofensores la ingenuidad de haberse creído sus iguales en fuerza, la tontería de haberle desafiado. No se podría equiparar a ellos, juzgando sus motivos, y castigándolos.

Pero este magnánimo perdón no es absolutamente desinteresado. El magnicidio frustrado que perdona detiene a las mentes conspiradoras, frustrándolas absolutamente, congelándolas en dicho estado de cristalización psíquica, precaviendo toda subjetividad rebelde. Livia tiene a su cargo la explicitación discursiva del finalismo político de esta mística del perdón (sirviéndonos de las claves de Charles Peguy, en Notre jeunesse ${ }^{47}$ ). Ella dice a Octavio Augusto al final de la escena III del acto IV:

Después de castigar en vano su insensatez, ensayad el poder de la benevolencia sobre Cinna. Haced que encuentre su castigo en la confusión; buscad lo más útil en este caso. Su pena irritaría más aún a la ciudad; el perdón puede contribuir a vuestro renombre y aquellos a quienes vuestro rigor no hace más que incitar, se dejarían atraer por vuestras bondades ${ }^{48}$.

Luego, ya sola, refiriéndose a él:

Él se marcha. Vamos con él y hagámosle ver que puede afirmar su poder otorgando su perdón. Y después de todo, la clemencia es la más bella muestra de cara al universo para demostrar que se es un verdadero monarca ${ }^{49}$.

Y hacia los versos finales de la última escena del acto V, Livia se solaza en la clemencia de Tito:

Una llama celeste ha iluminado mi alma con una claridad profética. Oíd lo que los dioses os hacen saber a través de mí. Esta es la ley inmutable de nuestro feliz destino: después de esta acción ya nada tenéis que temer. Desde ahora, todos se

\footnotetext{
46 Carta de Carlos V a su hermana Leonor, citada en CHABOD, Federico. Carlos Vy su imperio. Madrid: FCE, $1992,208$.

47 PeguY, Charles. Notre jeunesse. Paris: Éditions Gallimard, 1993.

${ }^{48}$ Corneille, Pierre, op. cit. (n. 29), p. 195.

${ }^{49}$ Idem, p. 196.
} 
someterán a vos sin quejarse y los más indómitos, cambiando totalmente sus intenciones, estimarán como dicha inmensa morir siendo vuestros súbditos. Ningún plan cobarde, ninguna envidia ingrata se opondrá al curso de una vida tan grande; ya no habrá jamás conspiradores y asesinos, porque habéis encontrado el arte de adueñarse de los corazones ${ }^{50}$.

Los conjurados ya no podrán volver sobre planes similares sin sentirse ridículos. El magnánimo perdón manipula extraordinariamente el futuro de toda conspiración posible. No permite a los conspiradores un futuro sino dentro de los límites del respeto al estado que es Augusto. Dice a esos conspiradores: no vuelvan a intentarlo porque si llegasen a lograrlo alguna vez, será únicamente porque yo les he permitido vivir para llevarlo a cabo. Ustedes no serán autores de su triunfo, seré yo.

-Divino Spinoza, perdóname. He perdido la cabeza.

El Premio Nobel yidish Isaac Bashevis Singer no pudo evitar a lo largo de su narrativa hacer referencias directas a la vida del filósofo sefardí Baruj Spinoza y al incomparablemente revolucionario pensamiento de aquel. Como el antisemita Schopenhauer o el J. L. Borges del poema al filósofo de Ámsterdam dedicado, I. B. Singer veía en Spinoza el ideal realista de un hombre radicalmente independiente. Independiente de la religión, independiente del Estado, los gremios, las ideas en boga e independiente de... la mujer. Solo en un judío culturalmente predispuesto a una diáspora permanente podía darse este caso sublime de libertad, de la autonomía que ni Kant supo darse con aquella abundancia de Voluntad, diría Schopenhauer. La antípoda existencial del Hegel ligado a todos los absolutos a mano, Spinoza, muy anterior, por supuesto, estaba lejano a las insoportables intrigas universitarias, permanecía noche y día en su cuchitril del gueto, tallando las lentes en su oficio de óptico, mientras pensaba solo exigiéndose y dándose cuentas a sí mismo. Al final, una sinagoga se dio el trabajo de condenarlo. El tipo de personalidad propia que ve proyectada I. B. Singer en Spinoza la encontramos en la novela El esclavo. Con posterioridad a las matanzas de judíos en la Polonia del s. XVII llevada a cabo por cosacos -más o menos contemporáneas a las persecuciones que llevaron a Spinoza de España a Holanda- Jacob, cuya familia ha desaparecido en la matanza, llega a servir como esclavo en una aldea de gentiles. Pero Jacob no está solo. Sus estudios rabínicos de la Mishná y la Gemará preservan de memoria en su mente las palabras que internamente lo hacen libre incluso sometido a esclavitud. Pero el afán libertario siempre culposo de Jacob va más allá. Se libera de su propia mente religiosa cuando se une secretamente a una mujer gentil, con la cual escapa de entre los polacos para vivir entre judíos que finalmente descubren a la polaca oculta en Sara, la mujer de Jacob ${ }^{51}$.

I. B. Singer, como digo, no podía evitarlo, quizás porque hallaba en su propio carácter un parecido, un precedente tradicional a su condición de intelectual enemigo de

50 Idem, p. 209.

${ }^{51}$ SINGER, I. B. El esclavo. Barcelona: Ediciones B, 2006. 
las ideologías del siglo XX, crítico del pueblo judío - una actitud, según el mismo, muy judía- y de la banalidad generalizada de los escritores. Su novela a ratos autobiográfica El certificado está plagada de comentarios a Spinoza ${ }^{52}$, y su cuento El Spinoza de la calle Market, también. La frase que cierra ese cuento la hemos anotado abriendo este fragmento. Nos da motivo para realizar ahora un alcance acerca del reproche a sigo mismo, y del perdón autoconferido.

Las traslúcidas manos del judío

Labran en la penumbra los cristales,

Y la tarde que muere es miedo y frío

(Las tardes a las tardes son iguales.)

Las manos y el espacio de jacinto

Que palidece en el confín del Ghetto

Casi no existen para el hombre quieto

Que está soñando un claro laberinto.

No lo turba la fama, ese reflejo

De sueños en el sueño de otro espejo,

$\mathrm{Ni}$ el temeroso amor de las doncellas.

Libre de la metáfora y el mito

Labra un arduo cristal: el infinito

Mapa de Aquel que es todas sus estrellas ${ }^{53}$.

El poema de J. L. Borges es el reverso poético de la costura prosaica del cuento de I. B. Singer. El cuento no es tan optimista. En este último, un doctor en filosofía, el Doctor Nahum Fischelson, vecino de la calle Market en Varsovia, no solo admira a Spinoza, cuelga de una pared el retrato de aquel y lee todo el día un ejemplar en latín de la Ética basada en la geometría con esmero anotado por todos sus márgenes, sino que además "Tenía la nariz ganchuda como un pico y sus ojos, grandes y oscuros, parpadeaban como los de un pajarraco" 54 . Hombre solitario y, como se ve, hasta parecido físicamente a su maestro, había interiorizado como ideas propias todo el sistema spinoziano. Sin familia, rechaza la compañía humana, se basta a sí mismo como esa parte armónica de la infinita res congitans cartesiana que es la psiquis humana, en Spinoza. Ya viejo y enfermo, no teme a la muerte. Mentalmente se recita el célebre fragmento en el libro cuarto de la Ética de Spinoza: "Un hombre libre en lo que menos piensa es en la muerte, y su sabiduría reside no en la reflexión de la muerte, sino en la de la vida (...)"55. En medio de los movimientos urbanos previos a la guerra, el doctor Fischelson enferma, y casi muere si no es por los cuidados de una vecina inoportuna, la ruda solterona Dobbe La negra, que, obviamente, no ha oído en su vida hablar de Spinoza. Fischelson mejora de salud y se repone casi totalmente. Dobbe quiere casarse con él. Los vecinos judíos organizan la boda según la

\footnotetext{
52 Singer, I. B. El certificado. Barcelona: Ediciones B, 2006.

53 Borges, J. L. "Spinoza” en: Antología poética latinoamericana. Madrid: Alianza Editorial, 1990.

54 Singer, I. B. "El spinoza de la calle Market" en su: El spinoza de la calle Market y otros 11 relatos. Barcelona: Plaza \& Janés, 1979, p. 5.

55 Idem, p. 6.
} 
tradición, y el Doctor Fischelson apenas puede cumplir con el ritual de quebrar la copa provocando las rudas risas de sus vecinos de la calle Market. La noche de bodas, Fischelson observa las estrellas en el universo, observa a esa totalidad divina de la cual él forma parte, totalidad que lo gobierna decidiendo hasta sus mínimos movimientos de anciano ahora casado. Spinoza había reformulado las dicotomías cartesianas reinterpretando el punto en que el pensamiento de Descartes convergía con el de San Anselmo de Canterbuy. Anselmo como Descartes coincidían en la comprobación conocida como "ontológica" de la existencia de Dios, aunque la propuesta de Descartes recogió, más bien, el legado de Anselmo y lo propuso por vía propia. En el entendido que Dios es infinito -y siguiendo la dicotomía res congitans (sustancia pensante)/ res extensa (sustancia extensa) para la comprensión certera del mundo- Spinoza propuso que Dios sí existía pero no podía ser una sustancia distinta de la sustancia llamada Mundo, pues, ¿cómo entonces podría ser infinito si dentro de su conjunto no estaban contemplados los elementos del conjunto llamado "Mundo"?, y ¿cómo a su vez podría haber una mente humana fuera de dicho conjunto infinito en que Dios y el Mundo se identifican? Pues bien, en toda su imperfección humana, el doctor Fischelson era para sí una parte de ese Mundo-Dios, y desde el ciego punto de vista de ese Mundo-Dios, era ese todo. ¿Cómo entonces se dejaba arrastrar al luminoso agujero de la mujer -el matrimonio- por una vecina ignorante de Spinoza, y, por tanto, tan ignorante de sí misma? Él intenta explicarle de manera didáctica las conclusiones materialistas y panteistas de Spinoza:

-Dios está en todas partes -contestó el anciano-. En la sinagoga. En la plaza del mercado. En esta habitación. Nosotros mismos somos partes de Dios.

-No diga semejante cosa -protestó Dobbe-. Me asusta ${ }^{56}$.

La vecina ya existía en la vida del Doctor Fischelson con aquella forma inofensiva de los buenos vecinos. Pero esta aparición deja de constituir una simple contingencia, de causas desconocidas, cuando Dobbe La Negra deja de ser la vecina repentina. En Los cuadernos de Malte Laurids Brigge, Rainer Maria Rilke, anota una exquisita y neurótica reflexión sobre la relación existencial que se establece con los vecinos:

Existe un ser que es por completo inofensivo. Cuando pasan bajo tu mirada, apenas los has visto y ya lo has olvidado. Pero, invisible, llega de algún modo a tus oídos, se desarrolla en seguida allí, brota, por así decirlo, y se han visto casos en que penetra en el cerebro y crece asolando ese órgano, de modo semejante a los pneumococos del perro, que penetran por la nariz ${ }^{57}$.

La obsesión por la aparición del extraño en la sociedad europea de finales del siglo XIX y principios del XX, llega hasta esa sofocante cima que fue El extranjero de Camus, o el famoso poema en la literatura europea oriental de O. W. de Ludbicz Milosz, La extranjera ("Yo no sé de tu pasado/ has debido soñarlo"58) pasando por el exotismo en la ópera

\footnotetext{
${ }^{56}$ Idem, p. 20.

${ }^{57}$ Rilke, Rainer Maria. Los cuadernos de Malte Laurids Brigge. Buenos Aires: Losada-Océano, 1999, p. 144.

${ }^{58}$ Ludbicz Milosz, O. W. de, "La extranjera” en su: Antología poética, Buenos Aires: Fabril Editorees, 1959 , p. 8.
} 
bizetiana, la pintura botánica selvática de Henri Rousseau, o las meditaciones egiptólogas de las piezas escultóricas de Amedeo Modigliani. Se trata, principalmente, de un desarrollo históricamente posterior a la filosofía de Hegel, a una revisita de la otredad como constitución de la subjetividad, un pensamiento socialmente presente, no solo en boga, aunque sin la inocencia anterior a los movimientos europeos de 1848. Resulta especialmente interesante el que la literatura europea haya vivido una obsesión con -en orden gradual- lo extraño, lo extranjero, lo vecino o lo próximo, al nivel de hacer de ello una definición de su propio quehacer ético y estético. Pero el exotismo es la exageración plástica de una escisión ontológica y epistémica. La constelación vecinal de personajes en I. B. Singer quizás tenga su precedente en esa galaxia de caracteres que en la comedie humane de Honoré de Balzac desarrolló una telaraña monumental de perspectivas. Aunque la telaraña de Singer es recatada, él concibió muchas de sus novelas en ese esquema de relatos vecinos, relatos que casi se visitan los unos a los otros (protagonistas aquí cruzan tangenciales allá) como en la trilogía cinematográfica Trois couleurs de Kieslowski. Con todo, la proximidad a la que llegan estos personajes - me refiero al Doctor Fischelson y a Dobbe- que podrían haber sido los protagonistas de relatos de tramas paralelas, aisladas hasta el punto de desarrollarse bajo títulos distintos, la proximidad, digo, los modifica aterradoramente. No es ya este un asunto que solo a las perspectivas compete; comienza a competer al origen y destino de ese todo que en Spinoza es Dios. Ahora bien, ¿qué tan próximas al desarrollo existencial, al despliegue de las cadenas causales, están la vecinas de Dr. Fischelson para él?, ¿y qué tan cerca suyo está, en particular, esta vecina? Lo está al punto que ya no podrán ser lo que son el uno sin el otro.

Pero esta especie de mujer simple de J. J. Rousseau, no es solamente una necesidad de senectud. Esta mujer es el enterramiento concreto de la filosofía de Spinoza, para quien -como es el caso del Doctor Fischelson- ha construido su forma de ser con prescindencia de la compañía femenina, de la compañía humana en general. Pero ¿qué dijo Spinoza sobre el matrimonio en el libro de cabecera de Fischelson, La ética? Señala en el vigésimo capítulo del apéndice:

Por lo que atañe al matrimonio, es cierto que concuerda con la razón si el deseo de unir íntimamente los cuerpos no es engendrado por la sola belleza, sino también por un amor de procrear hijos y educarlos sabiamente; y si, además, el amor de ambos -es decir, del varón y la hembra- tiene por causa no la sola belleza, sino, sobre todo, la libertad del ánimo ${ }^{59}$.

El problema teórico interno, sin embargo, está en que Fischelson necesariamente terminaría casado después de tantos años de soledad, soledad que desde ahora se ve carente de sentido. $\mathrm{Y}$ al clamar perdón para un asunto del cual tampoco aguarda otro castigo sino el de la decepción de sigo mismo, ¿a quién pide tal perdón? No se lo puede pedir, en realidad, al Spinoza concreto. Aquel ha desaparecido como entidad capaz de realizar el gesto comunicativo del perdón. No se puede pedir perdón a sí mismo pues, ¿qué exigencia normativa podría hacerse cuando, del punto de vista de su sistema de

\footnotetext{
59 SPINOZA, Baruj de. Ética demostrada según el orden geométrico. Madrid: Ediciones Orbis, 1980, p. 245.
} 
pensamiento spinoziano, su acto de matrimonio ha resultado de un engranaje causal por él desconocido? Seguramente podría llegar a entenderse que el Doctor Fischelson pide perdón por no haberse en tantos años realmente conocido, mas, ¿̇dónde está ahora la conciencia intelectual hacia la cual dirige su plegaria?

No está. Porque, en última instancia, no existe, como lo sostiene I. B: Singer en su impresionante cuento Shidda y Kuziba, cuento sobre demonios madre e hijo que no soportan la luz del universo:

Shidda sabía perfectamente que la victoria definitiva sería de las tinieblas. (...) Llegaría la hora en que se extinguiría la luz del universo; todas las estrellas se apagarían todas las voces serían silenciadas; todas las superficies destruidas; Dios y Satán serían uno solo. El recuerdo del hombre y sus abominaciones no sería sino un mal sueño que Dios había tejido durante cierto tiempo para distraerse en su eterna noche ${ }^{60}$.

Las estrellas hacia las cuales dirige su plegaria exculpatoria el Doctor Fischelson son tan pasajeras como él mismo disuelto, finalmente, en la inmensidad infinitesimal de un Dios que no existe pues no escucha nada. En esa nada, el castigo y el perdón ya sabemos hacia donde se dirigen. Sin embargo, recordemos las palabras del profeta Isaías que I. B. Singer cita hacia el comienzo de Sombras sobre el Hudson en el personaje de Boris Makaver: Dios no le habló mediante terremotos y tempestades, le habló mediante "uba débil, silenciosa voz"61 (I Reyes 19: 9-13).

\section{PASEMOS A Hungría}

Entre los autores que han llegado a nosotros con ocasión de la última y bullada "moda magiar”, está Dezso Kosztolányi. Aquel, contemporáneo de artistas como sus compatriotas los compositores etnomusicólogos Béla Bartók y Zoltán Kodály o el extraordinario poeta O. W. de Ludbicz Milosz, pero también de Béla Kun, y antecedente de otro gran escritor puesto en circulación por la máquina editorial, Sandor Marai, comparte con este predecesor suyo una nada ingenua nostalgia, que se nos aparece como "repentina", por el mundo del desaparecido Imperio Austro-Húngaro. La relectura de aquel monstruo burocrático, militar y cultural tan criticado por enormes corrientes nacionalistas dispares entre sí como la liberal de Manzzoni, Garibaldi o Verdi, por un lado, y la socialista de hasta Hitler, por el otro, a cuya revaloración ha llegado a aportar una mente tan maldita y arisca como la de Oskar Kokoschka, prototipo de artista degenerado -en su autobiografía-, había concitado una escasa y laxa militancia políticamente correcta ${ }^{62}$. Teníamos antecedentes de ello en ese emblema y epitafio de la poesía moderna que es The wastland, donde en su primera parte The Burial of the Dead, se incluían, a modo de repentino dejá vu ajeno, los siguientes misteriosos versos:

\footnotetext{
${ }^{60}$ Idem, p. 91.

${ }^{61}$ Singer, I. B. Sombras sobre el Hudson. Barcelona: Ediciones B, 2005, p. 18.

62 KOKOsChKa, OsKar, Autobiografía. Barcelona: Tusquest, 2002.
} 
And when we were children, stayind at the arch-duke's,

My cousin's, he took me out on a sled,

And I was frightened. He said, Marie,

Marie, hold on tight. And down we went.

In the mountains, there you feel free..

I read, much of the night, and go south in the winter ${ }^{63}$.

El primo archiduque, a quien rememora la mente que se atraviesa gramaticalmente por el poema como en una sesión espiritista, es uno más de los herederos directos al trono imperial. Este primo está cerca de quien habla y va con él sobre un trineo. La familia imperial de los habsburgo estaba presente cotidianamente entre sus súbditos como una especie de atmósfera repleta de un translucido incienso católico romano. Ello nos habla del mundo de la catolicidad redonda imperial, el de ese proyecto medieval de catolicidad que hallamos expuesto en De Monarchia, de Dante y en ciertos pasajes de La Divina Comedia. Ese ideal de Dante pasó a un lector renacentista del poeta florentino, el cardenal Mercurino di Gattinara, canciller del Sacro Imperio Romano Germánico, posterior a Chievrés, durante el pretendido universal gobierno de Carlos V, quien nos incluyó entre sus súbditos a nosotros, los chilenos. El Sacro Imperio de Carlos V intentó volverse expresión del programa dantesco ${ }^{64}$. Lo que de aquel proyecto quedó a modo de férreo despojo en lo que se llamó Imperio Austro-Húngaro hasta el periodo de entre guerras, fue la rememoración moderna y a ratos pluralista de aquel mundo perdido, el proyecto católico (universal) de Di Gattinara. En ese espacio político convivían las lenguas más mutuamente incomprensibles, y quien estaba a su cabeza, el emperador, había llevado su presencia física a cada rincón. Sandor Marai en su novela El último encuentro, conocida en una edición anterior con el título en castellano de $A$ la luz de los candelabros, incluye un pasaje donde el protagonista, un noble húngaro, recuerda la sobria habitación del castillo familiar en la cual se había alojado al Emperador - ese "alto funcionario del imperio", dice Marai- durante una de sus visitas a la localidad ${ }^{65}$. En ese mundo europeo donde la unidad espiritual "es fundamental para las doctrinas órficas y pitagóricas, para la harmonia mundi de Boecio y del siglo XVI", como nos refiere George Steiner en Después de Babel ${ }^{66}$. Cual Joseph Roth, en La Marcha Radetzky o en La cripta de los capuchinos, estos escritores húngaros se dieron a revalorar el mundo todavía demasiado presente, para su tiempo, de los habsburgo, en una época donde a artistas europeos de izquierda se los anatomizaba desde el Kremlin por su carácter "formalista". La encantadora historiadora Dorothy Gies MacGuigan no duda en afirmarlo en su libro sobre Los Habsburgo: "Los que fuimos al colegio entre las dos guerras mundiales, estudiamos a esta dinastía bajo un prisma de hostilidad. Los habsburgo españoles seguía viviendo a la sombre de la Leyenda Negra. Los

\footnotetext{
${ }^{63}$ Eliot, T. S.. La tierra baldía. Buenos Aires: Editorial Sol 90, 2003, p. 10.

${ }^{64}$ Sobre este asunto Soisson, Jean-Pierre. Carlos V. Buenos Aires: El Ateneo, 2005; ChAbod, Federico, op. cit. (n. 46) ; LAFAYE, Jacques. Sangrientas fiestas del Renacimiento. México D. F.: FCE, 1999.

${ }^{65}$ MARAI, Sandor. El último encuentro. Barcelona: Salamandra, 2002.

66 STEINER, George. "El saber literario del futuro" (de El castillo de Barba Azul) en su: Lecturas obsesiones y otros ensayos. Madrid: Alianza Editorial, 1990, p. 590.
} 
habsburgo de Austria tenían que sufrir , no solo los prejuicios de los historiadores protestantes del siglo XIX, sino la amargura constante de los nacionalistas que estuvieron presentes en la desmembración de la monarquía, en 1918 "67.

Novela elegante, desprovista de excesos y de improviso escalofriante, a Édes Anna (Anna la dulce), se la considera acaso la mejor obra de Dezso Kosztolányi.

Un aristócrata ligado a la tierra -el caso paradigmático de Tolstoi- conoce a su gente, desde los más humildes siervos que sirven en sus tierras hasta el emperador, y, para bien o para mal, todas las dignidades intermedias no les son desconocidas. Pero los burgueses solo se conocen entre sí, y desconfían de todo cuanto ocurra más allá de los límites de su círculo social. En un habitante de la periferia urbana no ven a un descendiente citadino de campesinos amigos; ven a un posible delincuente, un ente desprovisto de pasado común.

El matrimonio Vizy tiene un gran problema: ninguna de las criadas sirve como debiera. Béla Kun acaba de escapar en una avioneta de Hungría, los rumanos ya invaden Hungría "contraviniendo las prohibiciones de las grandes potencias" 68 , y no reparando demasiado en el entorno revolucionario, a ratos sofocado por los grupos reaccionarios, los Vizy viven su propia crisis matrimonial a propósito de una crisis mayor: escasez de competentes empleadas domésticas. Esta escasez dice relación con un problema de entorno: la sublevación generada de la servidumbre producto de la revolución comunista comandada por el, en 1919, dictador Kun. Maltratados por la criada Katica, la Señora Vizy decide emprender la tarea titánica -a ratos lindante con una crisis histérica- de buscar una nueva criada, y, si es preciso, robársela a algún vecino. Oye acerca de la discreta y trabajadora Anna. Logra traerla a casa, y entonces, todo cambia para los Vizy:

Despertó al alba, con las primeras luces, nerviosa y presa de una gran curiosidad.

Lo que vio la dejó boquiabierta.

La criada ya había barrido y ventilado las habitaciones.

¿Cómo era posible? La Señora Vizy no atinaba a entenderlo.

Debía de haberse levantado a las cuatro, como mínimo, y realizado sus quehaceres con tanto cuidado que no había provocado el menor ruido, hasta el punto de que ella ni se había enterado.

Anna estaba acurrucada detrás del escritorio del despacho; llevaba el vestido azul de algodón y los zapatos de hombre que al llegar guardaba en el hatillo.

La Señora Vizy se limitó a hacer un además con la cabeza. Sabía que no era prudente elogiar a las criadas al principio, pues si no se relajan ${ }^{69}$.

Anna funciona a la perfección. Los Vizy salen de viaje, queda en casa el sobrino Jancsi, y este decide: "ocuparse de Anna"70. "Ha llegado el momento -pensó-. Un chiste, un chiste vulgar, una cochinada como una casa. Y ella se reirá, perderá el equilibrio y caerá

\footnotetext{
${ }^{67}$ MaCGUigan, Dorothy Gies. Los habsburgo. Barcelona: Ediciones Grijalbo, 1970, p. 7.

${ }^{68}$ Kosztolányi, Dezs. Ana, la dulce. Barcelona: Ediciones B, 2003, p. 51.

${ }^{69}$ Idem, p., 87.

70 Idem, p., 143.
} 
de espaldas. A las criadas se las conquista así"71. Pero no fue tan fácil, no obstante el momento llegó para Jancsi:

Aquel calor prohibido era una delicia. Creyó que le subiría la fiebre de inmediato y que empezaría a arder. Extendió las piernas con un movimiento lento y lujurioso, acercándolas a la penumbra, a las profundidades desconocidas del mundo de las criadas donde intuía suciedad y sangre, algo asqueroso y terrible, quizás chinches y hasta sapos. Con dedos temblorosos acarició las deshilachadas sábanas de algodón.

Dio vueltas en la cama revolcándose cual si fuera un basurero, para ensuciarse lo más posible. Ya se había fundido con ella, ambos eran una y la misma $\operatorname{cosa}^{72}$.

Todo continúa como si nada. Pasan los días, Anna sigue en su abnegación. Repentinamente, al final de la gala por el nombramiento del Señor Vizy como secretario adjunto del Estado, Anna mata a sus patrones, sirviéndose de un cuchillo de cocina, luego de lo cual se queda dormida. Lo que sigue es el descubrimiento de los asesinatos, la detención de Anna, el comidillo vecinal, y el juicio a Anna, donde un juez de instrucción "tan aplicado como mal remunerado - pero que sin embargo Anna creyó- un hombre sumamente rico y poderoso"73 le da un trato digno y hace pasar al tribunal que finalmente la sentenciará a muerte, sin antes dejar de interrogar a testigos. Uno de ellos, al ser consultado por los jueces si acaso era pariente de Anna “(...)no contestó, sino que se limitó a sonreír ante la disparatada suposición de que él pudiera ser pariente de ella"74. Anna sin dilaciones confiesa sus actos. La confesión es aquí la facilitación de las diligencias judiciales.

De improviso, durante el juicio, el narrador transforma su forma verbal. Comienza a interpelar internamente a uno de los personajes, un anciano diabético, el doctor Moviszter, para que salga en defensa de Anna:

¿Dónde estás, viejo médico agonizante, diabético incurable? ¿Ya te has muerto o estás en tu cama, a punto de expirar, completamente desamparado, sufriendo el estado de somnolencia que suele preceder a la muerte de los diabéticos? ¿Has desaparecido dejando la tierra desierta? Si aún vives, si una última chispa de vida palpita dentro de ti, deberías presentarte ${ }^{75}$.

El médico Moviszter se hace oír por el tribunal bajo el impulso del mismo narrador: "grita como gritaron en su día tus verdaderos parientes, los sacerdotes heroicos de los primeros cristianos (...) los que discutían incluso con su Señor"76. El anciano sabe que el presidente lo escucha: "La trataban sin amabilidad. Sin sentimientos" 77 . A Anna se la considera una débil mental. Si libera de la pena de horca, pero deberá pasar quince años en cárcel.

\footnotetext{
${ }^{71}$ Idem, p. 147.

${ }^{72}$ Idem, p. 151.

73 Idem, p. 237.

${ }^{74}$ Idem, p. 246.

75 Idem, p. 249.

76 Idem, p. 250.

77 Idem, p. 251.
} 
El narrador nos hace ignorantes tanto como ignorante es él respecto de los pensamientos de Anna. Nuestra idea de Anna no es demasiado distinta de la de los Vizy. Kosztolányi nos obliga a participar con ellos de aquel pecado burgués, aquella culpa de desconocimiento más arriba señalada.

La piedad sexuada que por Anna nos atribuye Kosztolányi no quiere detenerse tan pronto. Anunciado ya con la cita a la misa de réquiem al principio de la novela, el punto de llegada es religioso.

La complejidad del mundo para Kosztolányi se da en las superficies. El juicio a Anna Étes, la versión inmediata de su conciencia inconexa de los hechos "criminales" en contraste a la versión mediata, de relato continuo y transparente de la fiscalía, su abogado defensor y los jueces parece sugerir una verdad contradictoria pero de una realidad negativa: lo que llamamos verdad sustantiva depende de una realidad lingüísticamente extraña al miasma de la materialidad del mundo, un homogéneo caos solo factible de ser comprendido acompañándose de una omnicomprensiva convención, una mentira inconsciente y por ello profunda. Esta condición no es superable.

Pero las superficies donde son posibles nuestras categorías, y el juicio que nos formulamos, comienzan a ser perjudiciales en cuanto no se experimentan según el concepto de superficie, sino cual si se identificaran con una totalidad fija. El poder judicial no es capaz de agudizar su lugar en esa superficie a fin de presenciar con cierta perspectiva aquella misma superficie. Participa horizontalmente de los elementos de aquella. Pretender un poder judicial capaz de tal proeza es, para nuestro autor, la ingenuidad más adecuada al proyecto ilustrado. Kosztolányi es un enemigo de la forma de superficie burguesa, pero también del comunismo, que revuelve la superficie sin realmente revolucionarla, sin superarla. Béla Kun, huyendo de Hungría con cálices y otros objetos preciosos no es distinto de los burgueses y sirvientas que rasgan vestiduras en torno a la criminal. Tampoco el padre de Anna, Istzván Étes, escapa a este reducto. Él participa del juicio para desprestigiar a su hija. Ahora tiene una segunda esposa. El matrimonio anterior -del que nació Anna- es parte de su personal "prehistoria". El pueblo es un censo de candidatos a burgueses.

Lo señala Péter Esterházy, Anna es "una asesina sin causa"78. Pero para regularizar la superficie es necesario tratarla tal y como si tuviera una causa perceptible, promover la actividad de los prejuicios epistémicos de la justicia. A pesar de sus reflexiones, el presidente del tribunal continúa el procedimiento:

El presidente sospechaba que había un secreto escondido que nadie, probablemente ni la misma acusada, conocía. (...) Sabía que un acto no puede explicarse con una sola razón, ni siquiera con varias, sino que detrás de cada acto hay una persona, toda una vida, que la justicia no puede abarcar ${ }^{79}$.

Cuando Moviszter se había dirigido sin elocuencia al tribunal, el público desdeñoso ve en ese anciano a "una persona con ciertas limitaciones". Encontramos, a renglón seguido, una sorprendente declaración de principios del tradicionalista católico Kosztolányi: "Unas

\footnotetext{
78 Esterházy, Péter. "Introducción” en Kosztolányi, Dezso. Ana, la dulce. Barcelona: Ediciones B, 2003 , p. 12.

${ }^{79}$ Corneille, Pierre, op. cit. (n. 31), p. 244.
} 
limitaciones sin las cuales su grandeza humana habría desaparecido, perdiéndose en el territorio estérilmente ilimitado de la libertad"80. El ius pudiendi-una rica expresión a través de la cual los seres humanos concretos legitiman sus actos agresivos- es la ignorancia superdotada cerrada al misterio religioso de la piedad. He aquí la imposibilidad autorreflexiva de la legalidad, su incapacidad de perdonar hasta autodestruirse confiando en la justicia divina. En la señal de Caín que prohíbe castigarlo pese a su crimen, se nos recuerda el imperio del misterio y se nos exige confiar en esa justicia más paciente. Plutarco lo dijo desde su sabiduría no intelectual: "la paciencia tiene más fuerza que la fuerza".

Basada en la novela Jeji Pastorkyña (La bella pastora) de la escritora checa Gabriela Preissová, Jenufa, la más viva y sentida de las óperas del compositor Leos Janácek, toma su título del nombre de la protagonista, una jovencita que no tiene buena suerte. En una aldea morava, en territorio del Imperio Austro-Húngaro, ella pertenece a una endogámica y atávica familia de campesinos que vive bajo el influjo sagrado de la elegante Viena imperial. Pero la joven Jenufa no pretende atravesar los límites de su aldea; ella simplemente está enamorada de su primo Steva Buryja, un joven e irresponsable líder natural, y ha quedado embarazada de él. El otro primo, Laca Klemen la pretende no obstante ella no le corresponde. Hasta este momento la historia podría ser la trama de un típico triángulo amoroso. Sin embargo, ocurren otras cosas. Celoso, Laca corta el rostro de su prima, dejándole un horrible tajo en la mejilla. Embarazada y con el rostro desfigurado, la madre adoptiva de Jenufa, Kostelnicka Buryjovka, autoritaria e intachable sacristina del pueblo, la esconde en casa. Recibe entonces a Steva Buryja que ha conseguido una novia muy conveniente, la hija de un juez de paz, y planea casarse con ella. Entonces Kostelnicka Buryjovka decide deshacerse del hijo común de Steva con Jenufa, para que así los planes sociales de aquel no se vean obstaculizados, y casar a Jenufa con el primo Laca, para quien no será problema esta mujer desvirgada. En un parto sumamente difícil Jenufa tiene al hijo, y a medias inconsciente le pone un gorrito rojo. Kostelnicka Buryjovka toma al recién nacido y se interna en las altas montañas. Abandona al bebé entre los altos hielos y una vez regresa a casa, convence a Jenufa de que el niño ha nacido muerto y que sus recuerdos de aquel vivo no son más que un sueño propio del delirio en el cual se encontraba. Jenufa acepta casarse con Laca. Además de los aldeanos, a la boda asisten Steva, su novia y los burgueses padres de ella. Pero entonces sucede lo imprevisto. Un pastor desciende de las montañas trayendo en sus manos al azul bebé congelado. Vestida de novia y con la mejilla atravesada por una enorme cicatriz Jenufa escapa con el cadáver, interrumpiéndose la boda. Ha reconocido el gorrito. Descubre que ha sido engañada por su madre adoptiva. El pueblo corre tras ella, diciendo que lapidarán al asesino. Entre los aullidos de Jenufa, la altiva Kostelnicka Buryjovka se recoge a sus pies y completamente postrada confiesa sus planes y su crimen. Entonces Jenufa la perdona, pero la policía se lleva a

${ }^{80}$ Idem, p. 252. 
Kostelnicka. Una vez a solas con Laca, lo perdona a él también. La más débil, abusada, y desde hace un tiempo la más fea, los perdona a todos, y se queda con el cadáver del hijo en los brazos. Pero mientras esto ocurre en los hechos concretos, la música de Leos Janácek alaba a la bella pastora, en una cascada de luz orquestal, a triple fortísimo, cuando las cuerdas y los bronces entran en máxima tensión, en un apagón anunciado y repentino, acaba la ópera.

Jenufa es esa forma de carácter humano al que Victor Hugo se referiría en Los Miserables, a propósito de ese personaje transmundano, Mademoiselle Baptistine, diciendo

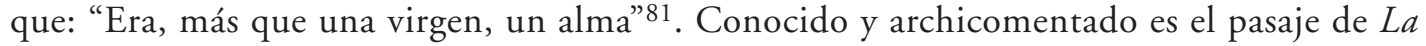
fenomenología del espiritu en que Hegel analiza el caso de la Antígona de Sófocles frente al tirano Creonte. Los argumentos de Hegel, muy criticados en su momento por un Goethe de ceño fruncido ${ }^{82}$, nos son alumbradores. Hegel ve en Antígona la representación de la ley de la familia, de aquella cerrada lógica de la estrecha alianza que une a los miembros de un hogar con sus muertos. Creonte, en tanto, desafiado por Antígona, significa el irrestricto predominio de la ley civil. Ambas leyes se enfrentan cuando Antígona desobedece el decreto de Creonte que sancionaba con la muerte a quien osara sepultar el cuerpo de Polínice, incestuoso hijo de Edipo y Yocasta -hermano a su vez de Antígona-, el cual había sumido a Tebas en una guerra civil. Antígona intenta sepultar a su hermano para dar cumplimiento a las leyes de los dioses del subsuelo, los dioses que guardan el mundo de los muertos. Creonte la castiga, sepultándola viva en una cueva. Hegel se negó a ver en este conflicto un burdo enfrentamiento entre buenos y malvados. Antes bien, quiso identificar una forma legislativa de tragedia. Una antinomia legal en principio irresoluble. La ley de orden cívico de Creonte contra la ley primitiva y telúrica de Antígona. El decreto de Creonte era ciego a la actividad angelical de Antígona, en tanto esta angelicalidad no era capaz de conferir un orden político a la comunidad en crisis. Pero la otra hermana, Ismena, que internamente desafía a Creonte, retrocede antes de exteriorizar su disidencia. En términos hegelianos, Ismena sería un alma bella, esto es, aquella que "ni siquiera puede enajenarse", que vive refugiada en su interioridad. Nótese, ahora, que cuando Jenufa perdona hacia el final de la ópera a su madre adoptiva, no impide el castigo que el estado, ciego al sentimentalismo del perdón, debe necesariamente darle a fin de preservar el orden adecuado de las cosas. Una Antígona lo hubiera hecho; una Ismena, no. Su acción bienhechora colapsa más allá de las fronteras de su psiquis. Se conforma con la paz de su mundo interior. El afuera cívico puede ser gobernado por otras fuerzas, tan extrañas a ella que no sabría desafiarlas. Ella no está hecha para gobernar como un Creonte ni para oponerse a él como una Antígona. Es el perdón cristiano de la interioridad.

Partidario de la antigua escuela de un socialismo humanista -ya desaparecido-, y, a un mismo tiempo, católico, Leos Janácek apareció con esta ópera después de nueve años del silencio que siguió a la muerte de su hija. Janácek estaba poseído por la reflexión acerca de una feminidad angelical, incapaz de odiar, incapaz de prologar el resentimiento -habitante terrenal del mundo sereno de los muertos-, pero no capaz de superarlo ética-

\footnotetext{
${ }^{81}$ Hugo, Victor. Los Miserables. Buenos Aires: Longseller, 2006, p. 19.

${ }^{82}$ Así en Goethe, Johann Wolfgang. “Conversaciones con Eckermann” en su: Obras completas. Madrid: Aguilar, 1974.
} 
mente, contractivamente, diría Kant. Lo interesante de tal forma de ser humano está en la naturalidad con la que emprende la altura de sus actos, en que sin siquiera proponérselo desafía la concepción de una humanidad cuya esencia es distinta a la naturaleza, disolviendo su deber en un santo y tierno deseo. La voluntad santa mencionada por Kant, y por él poco desarrollada.

El estado anímico de Leos Janácek lo mantuvo al margen de los grandes movimientos artísticos de su tiempo. Su ópera no fue aceptada en Viena. Se la consideró anticuada. Una especie de individuo gremial pero solitario, el propio Janácek no difería demasiado del alma bella hegeliana, no difería de su hija muerta ni de su hija viva: Jenufa. Su biografía es opaca por fuera, y brillante por dentro, sus óperas así lo demuestran.

El perdón de Jenufa, que no contempla al castigo como una alternativa, que no sostiene una relación dolorosa, moralmente atractiva, con un inexistente ánimo en ella de vendetta, ¿cómo significa perdón sin siquiera aproximarse a la posibilidad de un reproche? Es un perdón que emerge como el deus ex machina del cual ya hemos hablado, mas no desde la obvia exterioridad a la lógica del conflicto, sino curiosamente de la interioridad de su máquina conflictual, como si una máquina llegara a ser capaz de producir un sentimiento semejante a sí misma. Janácek no tiene otra mejilla que poner a su victimario, e incluso así perdona. Porque ella es toda una mejilla cortada.

Hasta aquí hemos podido hablar del perdón porque hemos podido hablar, al mismo tiempo, del reproche y la vía del castigo. Pero no hemos dicho nada acerca del perdón y el olvido, de la necesidad humana de no perdonar para de este modo llegar a no olvidar, a preservar más o menos intacta la reliquia del perdón que es el reproche. Se trata de una obsesión recordatoria que puede lindar la patología psiquiátrica. Esta forma del recuerdo no rememora, sino que vive su recuerdo como una experiencia presente, concreta y específica, imposible de ser abstraída por una mente esperanzada. Aun así, su imaginación es una indagación anestésica del pasado. El horror que provoca el futuro está dado por la posibilidad de una felicidad también anestésica, pero desprovista de esa moralidad involuntaria y permanente que es el recuerdo vivo.

La poeta soviética de origen ucraniano Anna Ajmátova, quien debía su pseudónimo al apellido de su abuela, una princesa tártara, escribió en su mente -no podía arriesgarse a ayudar su memoria escribiéndolo- uno de los más impresionantes poemas largos del siglo XX: Réquiem. Ajmátova apareció en la poesía rusa conjuntamente con los nombres de Osip Mandelstam, Marina Tsvietaiéva, Boris Pasternak, Nicolái Gumiliov o Fédor Sologub, quienes tuvieron en el ascético Alexander Blok a un guía poético-espiritual distante en quien los vicios autoritarios del líder estaban ausentes. Casada con el aristócrata y poeta Lev Gumiliov -luego de enviudar conviviría con el crítico de arte Nicolás Punin ${ }^{83}$-, Ajmátova estuvo al centro del grupo de vanguardia acmeísta, uno más de muchas pandillas que circulaban en la Rusia prerrevolucionaria. Pero el acmeísmo tenía una orientación más clásica que la independiente e izquierdista sucursal rusa del futurismo fascista de Marinetti, el de Mayakovsky, en cierto modo rival. En Mandelstam el acmeísmo mostraba una

83 Zgustova, Monika. "La casandra de San Petersburgo" en: Ajmátova, Anna Y Tsvietaiéva, Marina. El canto y la ceniza. Barcelona: Random House Mondadori, 2008, p. 264 y siguientes. 
nostalgia notoria por los valores clásicos de la antigua europa, del Dante y la Grecia pericleana; en Gumiliov, el acmeísmo pecaba de aquel ideal de aventura byroniano adicto a los viajes y a un exotismo reposado tan molesto para la intelectualidad obrera. Con Ajmátova, en tanto, el acmeísmo se transformó en una palabra que significaría un mundo de sensibilidades a contracorrientes de las determinaciones de la historia. Ajmátova dio a lo que registraban sus sentidos, a sus experiencias amorosas, a momentos cotidianos de su existencia solitaria, una densidad existencial tan delicada y poderosa que ella amenazaba -y esto no es una metáfora- la política brutal y empoderada de los soviets. "No es lo mismo ser poeta en Rusia que en Francia o Estados Unidos -escribe Natalia Pikouch-. En Rusia a los poetas se los toma en serio" ${ }^{84}$. Tan en serio que cuando las purgas estalinianas dirigidas por Nicolai Yezhov (también conocida como Yezhovchina), el hijo de Ajmátova y Nicolai Gumiliov, Lev Gumiliov, fue arrestado y mantenido prisionero durante meses en la prisión de Las Torres en Leninburgo. En 1921, el padre de aquel, había participado de una conspiración contra Lenin, y Lenin había gestionado su fusilamiento. Así, Réquiem de Ajmátova es una misa fúnebre en memoria de su esposo y en memoria actual de un hijo que está muerto y vivo, que permanece en una incertidumbre asfixiante, en la mitología bestial de una ansiedad siempre presente. En lugar de un prefacio, Ajmátova narra lo siguiente al inicio del poema:

En los terribles años de Yezhov, pasé diecisiete meses en las colas de las cárceles de Leningrado. En una ocasión, alguien, de alguna manera me reconoció. Entonces una mujer de labios azules que estaba detrás de mí, quien, por supuesto, nunca había oído mi nombre, despertó del aturdimiento en que estábamos y me preguntó al oído (allí todas hablábamos en voz muy baja):

$-Y$ esto, ¿puede describirlo?

Y yo dije:

-Puedo.

Entonces algo parecido a una sonrisa asomó lo que alguna vez había sido su rostro ${ }^{85}$.

Pese al estado en que se encontraba -sin dinero, viviendo de allegada, con "el marido en la tumba, el hijo en prisión/ rezad por mí una oración”86_, Ajmátova cree poder narrar no solo su sufrimiento, también el de las mujeres que la acompañan. Y es aquella posibilidad de narrarse a sí misma y a las demás, la única arma de la que dispone. Como creadora de convicciones estoicas, podrían citarse para su caso las palabras de Fedra en el verso 607 del acto II de la tragedia homónima de Séneca: "Las preocupaciones ligeras suelen hablar, las excesivas, quedar mudas" 87 . ¿Se nos aparece Hannah Arendt?, ¿aquella que reflexionando sobre la Acción en La condición humana, recurre a esa intuición de Isak Dinesen, que reza:" todas las penas pueden soportarse si las ponemos en una historia o contamos una historia sobre ellas"88? Este estoicismo queda brillantemente

\footnotetext{
${ }^{84}$ Pikouch, Natalia. "La poesía rusa y el siglo de plata" en Cinco poetas rusos. Bogotá: Editorial Norma, 1997, p. 33.

85 Ajmátova, Anna. Réquiem y poema sin héroe. Madrid: Cátedra, 1994, p. 103.

86 También en Ajmátova, Anna. Réquiem. Madrid: Mondarori, 1998, p. 54.

87 SÉNECA, Lucio Anneo. "Fedra" en su Tragedias. Madrid: Gredos, 2001, p. 46.
} 
expresado en la tercera sección del poema: "No, no soy yo, es otra la que sufre./ Yo no podría. Que ensombren/ lo ocurrido negros velos/ y retiren los faroles./ Noche...” ¿Se desdobla Ajmátova para que sea otra quien sufra por ella? La distancia que intenta tomar el estoicismo ante el sufrimiento a fin de poder comprenderlo, diagnosticarlo, empuja a Ajmátova hacia una experiencia del sufrimiento mediado por la poesía. Para no sufrir la desilusión de una felicidad imposible, ya no anhela nada: "Yo aquí renuncié a todo,/ a todos los bienes terrenales" 89 , declara en Los bocetos de Komarovo, y posteriormente: "Todos somos huéspedes de la vida,/ vivir es una costumbre". Entonces, de improviso el poema se ilumina: "hay una rama oscura, fresca, de saúco./ Es un poema de Marina". Se ha topado con un poema de Marina Tsvietaiéva, la otra poeta rusa con quien se admiró pero nunca llegó a conocer. Ajmátova puede soportar porque ve un poema en el horror. Con todo, la salida no es fácil. Esta forma de experimentación incluye a su vez una irrefrenable tendencia a la pérdida de sensibilidad, al endurecimiento del corazón como se ve en El veredicto, también parte del Réquiem.

Y cayó la palabra de piedra sobre mi pecho todavía vivo.

No importa. Estaba preparada,

De alguna manera me las apañaré.

5 Hoy tengo que hacer muchas cosas:

Hay que matar la memoria,

Hay que petrificar el alma,

Hay que aprender de nuevo a vivir.

si no... el caluroso susurro del verano,

10 Celebra su fiesta en mi ventana.

Hace tiempo que lo presentía,

Este día luminoso y la casa vacía ${ }^{90}$.

Es la traducción de García Gabaldón. Las resoluciones de la segunda estrofa (versos 6-8) presentan un aparente giro a la idea dominante. Ajmátova es capaz de narrar poéticamente la vida de aquellas mujeres que se levantan de madrugada para después de hacer una larga cola, entregar un pote de comida a los gendarmes de la cárcel al interior de la cual sus hijos están desaparecidos. Si la comida vuelve -nadie dentro la recibe- lo peor debe ser supuesto. Pero personalmente, ¿puede ella contra el veredicto?, ¿el veredicto del castigo sin sentido? Aquel castigo que, siguiendo las ideas de Dostoievsky -a quien Ajmátova prefería por sobre Tolstói, según lo confesó a Isaiah Berlin ${ }^{91}$ - no redime ninguna culpa por sí solo no obstante sea el hombre quien pueda conferirle un valor singular y

\footnotetext{
${ }^{88}$ Citado en ARENDT, Hannah, op. cit. (n. 17), p, 199.

89 Ajmátova, Anna. "Bocetos de Komarovo" en: Ajmátova, Anna y Tsvietaiéva, Marina. El canto y la ceniza. Barcelona: Random House Mondadori, 2008, p. 97.

90 Ajmátova, Anna. "Réquiem” en su Réquiem y poema sin héroe. Madrid: Cátedra, 1994, p. 117.

${ }^{91}$ IgNatiefF, Michael. Isaiah Berlin: su vida. Madrid: 1999, Taurus, pp. 35-50.
} 
único para sí mismo, puesto que aquel solo abusa. Ajmátova recordaría por las demás mujeres, salvaría para la posteridad sus experiencias compartidas, pero ante el sufrimiento de su hijo, solo le queda "matar la memoria" para así "petrificar el alma". Y ello se lo impone en una suerte de lista de tareas a realizarse diariamente (v. 5). Fechada su escritura por la propia Ajmátova el 22 de de junio 1939, coincide con el preciso día en que Lev Gumiliov fue sentenciado a un campo de trabajos forzados ${ }^{92}$. Resulta escalofriante el que Ajmátova haya podido escribir este pasaje de su Réquiem en un momento tan complejo para ella. Ello habla de un compromiso artístico que aún sumida en un golpe terrible es capaz de sentir el "caluroso susurro del verano" que "celebra su fiesta en mi ventana" aun cuando ella presente este fenómeno exterior a su dolor como una paradoja cuya participación plena de ese dolor. La naturaleza por entero se halla celebrando en un "día luminoso" y ella permanece en su casa "vacía" de Fontanka, separada de sus amigos quienes, también acosados por el régimen comunista, se ven obligados a rehuirse los unos a los otros a fin de sosegar las sospechas, mudos al interior de sus propias habitaciones o hablando en clave porque los micrófonos muchas veces -y especialmente a partir de los años cuarenta- estarán allí, a vista y presencia de sus víctimas como la maligna e "inmensa estrella", tomada de $E l$ idiota de Dostoievsky93, que observa a Ajmátova "la mira fijamente a los ojos" y la "amenaza con una muerte cercana" en el quinto movimiento del mismo poema ${ }^{94}$.

En el último movimiento del poema, Ajmátova presiente la posibilidad de un futuro incluso peor o tal vez más feliz para ella, pero en ninguna de sus hipótesis renuncia al recuerdo

De nuevo se acerca del recuerdo la hora, A vosotras os veo, os oigo, os siento ahora:

a ti, que llegar a la ventana apenas pudiste, a ti, que no pisaste tierra en que naciste,

5 a ti, que sacudiendo la hermosa cabellera, dijiste: "vengo aquí como si a casa fuera".

A todas por sus nombres quisiera evocar, la lista me arrancaron y ahora dónde buscar.

He aquí una gran manta para ellas tejida

10 de pobres palabras de ellas oídas.

De ellas me acuerdo siempre y por doquier ni en las nuevas desgracias las olvidaré,

y si me amordazan la boca de tormento atrita por la que un pueblo de cien millones grita,

\footnotetext{
92 García Gabaldón, Jesús. nota 10 en Ajmátova, Anna. Réquiem y poema sin héroe. Madrid: Cátedra, 1994, p. 117.

93 García Gabaldón, Jesús. nota 6 en Ajmátova, Anna. Réquiem y poema sin héroe. Madrid: Cátedra, 1994, p. 115.

94 Ajmátova, Anna. "Réquiem" en su: Réquiem y poema sin héroe, op. cit. (n. 93), p. 115.
} 
15 que sea posible que ellas en su pesar me eleven en la víspera del día que a la tierra me lleven.

Y si en este país en un cierto momento tienen la idea de hacerme un monumento, acepto que este homenaje me advoquen. pero solo a condición - que lo coloquen

no junto al mar donde vine a nacer: los últimos lazos con el mar desgarre, ni en el parque junto al tronco venerable, donde me busca la sombra inconsolable,

25 sino que aquí ante las puertas donde estuvieron mis pies trescientas horas y no me abrieron.

Porque temo en la muerte de dicha consueta, olvidar el tronar de las negras furgonetas, olvidar la odiosa puerta de golpe cerrada, y el grito de la anciana como bestia lanceada.

Y ojalá en los pétreos párpados sin vida como lágrimas corra la nieve fundida,

y la paloma de la cárcel arrulle en tierra nueva, y en silencio naveguen las naves por el $\mathrm{Neva}^{95}$.

Aunque esta traducción de Reina Palazón resulta menos dura que la de García Gabaldón, Zgustova o García Valdés, de alguna manera mantiene la sonoridad rimada del verso en ruso. En el primer verso encontramos la evocación del momento de la misa ortodoxa -como la católica- en el cual los difuntos son rememorados, son traídos por un instante a la vida. "La hora del recuerdo" se acerca "de nuevo" como un recurrente portal cuántico que de la ceremonia religiosa se apodera por efecto de las palabras claves del sacerdote ortodoxo (la hora del recuerdo, un conjuro), y es entonces que Ajmátova "ve", "oye" y "siente" a sus compañeras bajo el terror (v. 2). En su calidad de saludable psíquico, el poeta -Dichter, ese pastor del ser que es aquel según Heidegger- se reúne con aquellas tenues presencias en un trance que físicamente le afecta. Del tercer al séptimo verso las repasa una por una, vuelve a conocer sus historias individuales, las órbitas propias que les han dado reunión. Y, de improviso, esta suerte de trance se interrumpe cuando Ajmátova descubre que la lista de nombres -los nombres, aquellas palabras gracias a las cuales los recuerdos de aquellas mujeres pueden vocalizarse- ha sido requisada por la policía. Un

95 Ajmátova, Anna. Réquiem. Madrid: Mondarori, 1998, pp. 63-65. 
golpe a la memoria: la hoja de papel ha desaparecido. Se cumple así la profética aprehensión del rey en el Fedón de Platón. La invención de la escritura autorizaría al hombre a olvidar, lo confiaría en un archivo externo a los cuidados que de la memoria humana hacen los sentimientos a los recuerdos asociada. Sin embargo, Ajmátova, en su calidad de poeta, "de interlocutor de los bosques" 96 , según reza su poema La muerte del poeta, de 1960, salva todas esas palabras que oyó emerger de las bocas de aquellas mujeres, esas palabras sentidas que dicen más que los meros nombres, los apelativos, tejiendo con ellas un manto -el poema Réquiem-, un "vasto sudario", coinciden en traducir García Gabaldón, Zgustova y García Valdés (v. 9-10). El sudario, la material presentación de los dolores humanos de la deidad: la encarnación física del recuerdo. Ante la expectativa de una felicidad postrera la felicidad de la nada, de ya no estar, la muerte Ajmátova "teme" abandonar su tarea moral. Teme perdonar debido al simple olvido promovido por una nueva dicha (v. 27). Prefiere sufrir cuando de ello depende no abandonar el deber que está en sufrir a causa de los otros.

Por ello, pide a la naturaleza que una vez deje ella de existir, esta asuma el papel de representar estéticamente su sufrimiento: "Y ojalá en los pétreos párpados sin vida/ como lágrimas corra la nieve fundida” (vs. 31 y 32). En la hipótesis de un monumento en su memoria, Ajmátova quiere ver la nieve derretirse por sobre aquel como si se tratara de una catarata de lágrimas

Abrasada por el fuego de los dioses, del que eran víctimas los poetas, según Hölderlin, Ajmátova no olvidaba, era la conciencia moral inflexible de su tiempo como lo fue Pasternak, posteriormente Aleksandr Solyenitsin o antes que ellos Aleksr Pushkin frente al embrutecimiento zarista. Era una representante del pasado clásico ruso - "un icono ruso" escribirá Jorge Edwards, quien la conoció en París en una fiesta donde ella no se divertía ${ }^{97}$-, un símbolo de lo menos violento de la Rusia zarista y del decimonónico y esteta San Petersburgo pero también de una modernidad que para Ajmátova se frustró en Rusia pese a la pretensión de la NEP o la de los planes quinquenales. Ajmátova era admiradora distante de la modernidad. Así lo declara en su obra sumaria Poema sin héroe, donde la multitud de seres que habitan sus recuerdos - de su vida presente- participan de una simultánea e inmensa mascarada. Están allí Mayakovsky, Pasternak, Berlin, Tsvietáieva, y tantos otros amigos y enemigos en ese entonces ya desaparecidos, suicidados o moribundamente vivos. En uno de sus ataques de glosolalia, Tsvietáieva declaró en delirio afectivo con un poema a Ajmátova luego musicalizado por Dmitri Shostakovich (la traducción es de Reina Palazón):

¡Oh musa del llanto, la más bella de las musas!

¡Oh, tú, alocado engendro de la noche blanca!

Tú envías la negra borrasca sobre Rusia

$\mathrm{Y}$ tus gritos se nos clavan como lanzas ${ }^{98}$.

\footnotetext{
${ }^{96}$ Ibid., p. 100.

${ }^{97}$ EDWARDS, Jorge. Adiós, poeta. Barcelona: Tusquest, 1990, p. 166.

98 Tsvietáieva, Marina. “Oh musa del llanto" en su Antología 100 poemas. Madrid: Visor Libros, 1997, p. 61.
} 
A Ajmátova "le amordazaron la boca" mediante un oficial pacto de silencio en torno suyo, pero en su reemplazo la santa Rusia dostoievskiana a la cual ella había querido, autoexigente, representar, habló por sí misma. Así lo supo la poeta cuando de visita en un hospital de campaña hacia el final de la Segunda Guerra, recitó algunos de sus poemas, y, para su impresión, la multitud allí expectante comenzó no solo a recitarlos con ella al unísono, sino que la corrigió cuando ella equivocó las palabras. Como no existían libros de Ajmátova desde hace mucho tiempo, su poesía se había transmitido de forma oral, siendo recogida por universitarios quienes la mimeografiaban (al parecer no estaban tan ansiosos por salir el fin de semana) o bien simplemente habían sido anotados en cajetillas de cigarrillos, las paredes interiores de las casas o en las cortezas de los árboles. Ajmátova supo entonces cuán importante había sido ella para quienes solo se había, oficiosamente, dado a representar sin ningún mandato. Stalin, enterado, mandó averiguar quién había organizado aquella aclamación a una mujer que según Mayakovsky -suicidado varios años antes- no era más que parte de "simples hitos literarios, epígonos de un orden que se derrumba, no son más que inútiles, lamentables y ridículos anacronismos" 99 .

Ajmátova significaba una extraña alteración para las leyes de la historia. Se creía guía, junto a Tsvietáieva, de Rusia contra un universalismo perverso:

Juntas, hoy, Marina, caminamos

por Moscú en medio de la noche;

como nosotras, millones nos siguen

en un cortejo silencioso.

A nuestro alrededor suena a muerto

y ruge la tormenta de nieve

cubriendo la huella de nuestros pasos ${ }^{100}$.

Como se ve, para el poeta extraordinario que fue Mayakovsky, ella estaba destinada a desaparecer, no de la historia, pero sí de futuro vivo de una Rusia que renacía. En este sentido, este totalitarismo poético que lo afectó, no negaba la calidad estética de la obra de Ajmátova; la declaraba excluida del futuro pero no de la visión antológica de la historiografía literaria. Ajmátova presentía, por su parte, que aun cuando ella y Tsvietáieva dirigieran un amplio concepto moral de su patria: "ruge la tormenta de nieve/ cubriendo la huella de nuestros pasos".

La experiencia presente de los hechos desaparecidos, seguramente toda una patología, no hacían de Ajmátova una mera nostálgica. "Apenas recordamos el camino hacia esa casa perdida", dirá en Cuarta elegía del norte ${ }^{101}$, de 1953. Siguiendo la tesis de Zgustova, Ajmátova era "una casandra de San Petersburgo", esto es, una sacerdotisa de Apolo dignificada por el daño ocasionado por el don con el cual carga, el don de la videncia. Ella aterrada conoce el futuro ("No importa, ya lo presentía”; "y si en este país en cierto

\footnotetext{
99 Tomado del duodécimo volumen de las obras completas de Vladimir Mayakosvky y citado en GARCíA GABALDÓN. "Introducción" en AJMÁTOVA, Anna, op. cit. (n. 93), p. 63

100 Ajmátova, Anna. “¿Es tu doble?” en Ajmátova, Anna Y Tsvietaiéva, Marina, op. cit. (n. 89), p. 98.

101 Ajmátova, Anna. "Cuarta elegía del norte” en: Ajmátova, Anna Y TSVietaiéVA, Marina, op. cit. (n. 89), p. 113.
} 
momento/ tienen la idea de hacerme un monumento"). Es más, ella renuncia a su pasado personal ("no junto al mar donde vine a nacer:/ los últimos lazos con el mar desgarre,// ni en el parque junto al tronco venerable,/ donde me busca la sombra inconsolable,) en atención al dolor compartido con las demás mujeres de la cárcel ("si no que aquí donde estuvieron/ mis pies trescientas horas y no me abrieron").

En el portal de la vieja mansión rococó de Fontanka Dom, lugar donde Ajmátova ocuparía durante muchos años una única habitación junto a su hijo Lev, se hallaba la siguiente divisa, incorporada a modo de epígrafe al prólogo de Poema sin héroe:

Deus conservat omnia ${ }^{102}$

El emblema heráldico de la familia Sheremetev "Dios lo conserva todo", traducible la forma verbal conservat por "observa", "salva”. Ella tomó por emblema esta antigua idea judeocristiana en tres palabras latinas expresada, y la practicaba en su relación con las cosas. Pudo quemar miles de poemas, luego de escribirlos, porque sabía que una externa psiquis universal los conservaría. Sin embargo, sentía el deber de conservar en sí misma el dolor de las vidas ajenas. Hacer por los otros lo que los dioses atentos a la belleza, pero desdeñosos del dolor, hacían por ella, pero, menos evidentemente, por los demás. Así, en el fragmento Crucifixión, cristológicamente identifica a su hijo con el hijo de Dios y a ella con María, a quien al pie de la cruz: "nadie se atrevió a alzar los ojos"103. Ajmátova recordaba que Dios no solamente conserva todo lo pasado sino también todos los posibles futuros. No en el olvido sino en la observación, en la conservación del recuerdo pese a todas las explícitas e implícitas torturas, el hombre es salvado, es perdonado.

\section{FINALMENTE}

Qué es una reflexión sobre el perdón y la eventualidad del castigo en el supuesto sino la pregunta por la mejilla cristiana. "Pon la otra mejilla". El paso de una mejilla a otra pudo transformarse en una costumbre gracias a una legislación al efecto, pero entonces una escisión apareció en la historia ética de la Cristiandad. Por una parte, el derecho romano y el germánico continuaron comportándose como si a ellos la nueva ley judía no les competiera; por la otra, la moralidad del perdón pudo operar a modo de opciones privadas y con el auge inaugural de ciertos piadosos monasticismos. La distinción entre Derecho y moral que vino recién a ponerse en práctica con la división Iglesia-Estado, y que tanto escandalizó a la Iglesia, operaba ya desde antes mediante los efectos en la práctica de la distinción castigo y perdón. El imperio de la ley suponía el castigo. No se concebía ni un orden feudal ni uno imperial sin esta atribución propia de juzgador y ejecutor. Pero, en cambio, el perdón, elemento principalísimo de la novedad cristiana, solo pudo tener sentido como opción privada, como moralidad individual, diríamos hoy, nunca como imposición legal. Las numerosas amnistías no tenían tanto una finalidad evangelizadora como antes bien, una finalidad propiamente tal, la de aplastar el terreno disparejo

102 Ajmátova, Anna. op. cit. (n. 93).

103 Ajmátova, Anna. "Crucifixión” (De Réquiem) en Ajmátova, Anna y Tsvietaiéva, Marina, op. cit. (n. 89), p. 48. 
del pasado al objeto de garantizar a la comunidad política un futuro menos cerrado. La complejidad de esta cuestión radica en que la escisión castigo/perdón no operaba en los mismos rieles que la de derecho/moral, principalmente debido a que castigo/perdón y derecho requerían en alguna de sus partes de una legislación mundana preexistente; la moral, como se la concibe desde nuestros prejuicios modernos, se la ha definido como esencialmente distinta a la legislación (al aparato creador de la ley positiva), por ello mal podría proponérsela cual ocasión o equivalente al perdón en sentido históricamente estricto.

La mejilla anterior son todos los sucesos de la víctima cuando ha descubierto que todavía posee una nueva mejilla que dejarse agredir, y es más, puede proponerla a su agresor para que la agreda. El cristianismo podía entregar la mejilla posterior pese a todas las mejillas anteriores porque era un pensamiento religioso confiado del futuro. A diferencia del pensamiento trágico griego y el aún trágico que subsistía en Roma, el pensamiento cristiano creía que solo el plan divino, la lógica de la historia sagrada, era tan inevitable como una tragedia, no obstante, ser una tragedia repleta de felicidad y promesas de bienestar abundante.

Pero el perdón no pudo ser impuesto como la fe cristiana sí pudo serla mediante las conversiones coactivas pese a censuras tales como la de San Agustín.

La suspensión que el perdón supone en la ontología práctica de aquello que Fichte o Schopenhauer llamaban el Carácter, no es dependiente de una ingenuidad consustancial a ese mismo carácter. Se trata de un extraño imperativo infinito que Orland Patterson en el famoso ensayo La libertad, concibe como válido para un contexto bastante determinado: el del advenimiento inminente del reino de los cielos durante el ministerio de Jesucristo, haciéndose así eco de una vieja tesis a anticristiana.

Dicho reino hasta hoy está pendiente.

\section{REFERENCIAS BIBLIOGRÁFICAS}

Ajmátova, Anna y Tsvietaiéva, Marina. El canto y la ceniza. Barcelona, Random House Mondadori, 2008.

AjmÁtova, Anna. "Réquiem” en su Réquiem y poema sin héroe. Madrid, Cátedra, 1994.

Ajmátova, Anna. Réquiem y poema sin héroe. Madrid, Cátedra, 1994.

Ajmátova, Anna. Réquiem. Madrid, Mondarori, 1998.

ARENDT, Hannah. La condición humana. Barcelona, Paidós, 1993.

Borges, J. L.. "Spinoza” en Antología poética latinoamericana. Madrid, Alianza Editorial, 1990.

BRUCKNER, Ferdinand. Isabel de Inglaterra. Buenos Aires, Nueva Visión, 1961.

Chiarini, Paolo. Bertolt Brecht. Barcelona, Nexos, 1994.

Corneille, Pierre. “Cinna” en su Teatro trágico, Madrid, Emecé, 1968.

Corneille, Pierre. "Cinna” en su Teatro trágico, Madrid, Emecé, 1968.

Dion CASIO. Historia de Roma. Madrid, Gredos, 2004.

EDWards, Jorge. Adiós, poeta. Barcelona: Tusquest, 1990.

Eliot, T. S.. La tierra baldía. Buenos Aires, Editorial Sol 90, 2003.

ELIOT, T. S.. Muerte en la catedral. Madrid, EPESA, 1961. 
Esterházy, Péter. "Introducción” en Kosztolányi, Dezs . Ana, la dulce. Barcelona, Ediciones B, 2003. García Gabaldón, Jesús. nota 10 en AjMÁtova, Anna. Réquiem y poema sin héroe. Madrid, Cátedra, 1994. GOETHE, Johann Wolfgang. "Conversaciones con Eckermann” en su Obras completas, Madrid, Aguilar, 1974. Heidegger, Martin. La fenomenología del espiritu de Hegel. Madrid, Alianza Editorial, 1992.

Hugo, Victor. Los Miserables. Buenos Aires, Longseller, 2006.

IGNATIEFF, Michael. Isaiah Berlin: su vida. Madrid, Taurus, 1999..

JaCOBS, René. "Sept idées fixes (et fausses) su La Clemence de Titus" en su La clemenza di Tito, Italia, Harmonia Mundi, 2006.

Jaeger, W. Paideia y cristianismo primitivo. Ciudad de México, FCE, 2005.

JORDAN, David P. Robespierre, el primer revolucionario. Barcelona, Vergara, 2004.

KierkegaARD, Sören. Temor y temblor. Buenos Aires, Losada, 1999.

KoKOschKa, Oskar, Autobiografía. Barcelona, Tusquest, 2002.

Kosztolányi, Dezs. Ana, la dulce. Barcelona, Ediciones B, 2003.

Kuna, Franz. El teatro de T. S. Eliot. Ciudad de México, FCE, 1971.

LAFAYE, Jacques. Sangrientas fiestas del Renacimiento. México D. F., FCE, 1999.

LE MAUSS, Marcel. "Ensayo sobre los dones, los intercambios en las sociedades primitivas", en su Sociología y antropología. Madrid, Tecnos, 1971.

Ludbicz Milosz, O. W. de, "La extranjera" en su Antología poética, Buenos Aires, Fabril Editores, 1959.

MACGUIGAN, Dorothy Gies. Los habsburgo. Barcelona, Ediciones Grijalbo, 1970.

MANN, Thomas. José y sus hermanos, las historia de Jaacob. Barcelona, Ediciones B, 2000.

MARAI, Sandor. El último encuentro. Barcelona, Salamandra, 2002.

MARKale, Jean. El enigma de los cátaros, la masacre de Montségur, Buenos Aires, El Ateneo, 2008.

Peguy, Charles. Notre jeunesse. Paris, Éditions Gallimard, 1993.

PIKOUCH, Natalia. "La poesía rusa y el siglo de plata" en Cinco poetas rusos. Bogotá, Editorial Norma, 1997.

RILKE, Rainer Maria. Los cuadernos de Malte Laurids Brigge, Buenos Aires: Losada-Océano, 1999.

Rops, Daniel. La iglesia de la catedral y la cruzada. Barcelona, Luis de Caralt, 1956.

SCHILler, Johann Friedrich. María Estuardo. Madrid, Club internacional del libro, 1998.

SÉNECA, Lucio Anneo. "De la clemencia" en su Tratados morales. Ciudad de México, Universidad Autónoma de México, 1944.

SÉnECA, Lucio Anneo. "Fedra” en su Tragedias. Madrid, Gredos, 2001.

Singer, I. B. "El spinoza de la calle Market" en su El spinoza de la calle Market y otros 11 relatos. Barcelona, Plaza \& Janés, 1979.

SINGER, I. B.. El certificado. Barcelona, Ediciones B, 2006.

SINGER, I. B.. El esclavo. Barcelona, Ediciones B, 2006.

Singer, I. B.. Sombras sobre el Hudson. Barcelona, Ediciones B, 2005.

Soisson, Jean-Pierre. Carlos V. Buenos Aires, El Ateneo, 2005.

SPINOZA, Baruj de. Ética demostrada según el orden geométrico. Madrid, Ediciones Orbis, 1980.

STEIner, George. "A través de ese espejo, en enigma” en su Pasión intacta, Madrid, Ediciones Siruela, 1997.

STEINER, George. "El saber literario del futuro" (De El castillo de Barba Azul) en su Lecturas obsesiones y otros ensayos. Madrid, Alianza Editorial, 1990. 
STEINER, George. "Santa Simone: Simone Weil” en su Pasión intacta, Madrid, Ediciones Siruela, 1997.

STEINER, George. Antifonas, la travesía de un mito universal por la historia de occidente. Barcelona, Gedisa, 1996.

STEIner, George. La muerte de la tragedia, Caracas, Monte Ávila, 1970.

Tsvietáieva, Marina. "Oh musa del llanto" en su Antología 100 poemas. Madrid, Visor Libros, 1997.

Wittgenstein, L. Diario filosófico (1914-1916). Planeta-De Agostini, 1986.

Wittgenstein, L. Observaciones. Ciudad de México, Siglo Veintiuno editores, 1981.

Zgustova, Monika. "La casandra de San Petersburgo" en Ajmátova, Anna Y

Tsvietaiéva, Marina. El canto y la ceniza. Barcelona, Random House Mondadori, 2008. 
